\title{
POLIMORFISMO CONSTITUCIONAL DO DIREITO DE RESISTÊNCIA EM PORTUGAL
}

\section{CONSTITUTIONAL POLYMORPHISM OF RIGHT TO RESIST IN PORTUGAL}

\author{
José Domingues \\ Professor auxiliar da faculdade de Direito \\ Universidade Lusíada - Norte (Porto)
}

SUMÁRIO: I. INTRODUÇÃO.- II. POLIMORFISMO DO ARTIGO $21^{\circ}$ DA CRP.- III. A LINHAGEM PRÉ-CONSTITUCIONAL DA LEGÍTIMA DEFESA. - IV. POLIMORFISMO DO DIREITO DE RESISTÊNCIA NA CRP.- V. A GENEALOGIA PRÉ-CONSTITUCIONAL DO DIREITO DE RESISTÊNCIA COLETIVO.- VI. A GENEALOGIA PRÉ-CONSTITUCIONAL DO DIREITO DE RESISTÊNCIA INDIVIDUAL.- VII. CONCLUSÃO.

Resumo: O atual texto da Constituição da República Portuguesa agrega debaixo da mesma norma jurídica (art. ${ }^{\circ} 21^{\circ}$ ) várias formas de resistência constitucional. Este artigo, numa perspetiva histórica, vai recuperar algumas das múltiplas formas de manifestação do direito de resistência em Portugal, v. g., a legítima defesa, o direito de resistência popular e o direito de resistência individual. $O$ primeiro objetivo é, não sendo aconselhável uma separação estanque, contribuir para uma possivel diferenciação entre cada uma dessas formas. O segundo objetivo deste trabalho é o de combater a tese de que o direito de resistência popular teria sido transformado, pelo constitucionalismo moderno, num direito de resistência individual para defesa dos direitos fundamentais consignados na Constituição. Desta forma, o elemento histórico poderá ser um contributo para a interpretação do referido preceito constitucional sobre o direito de resistência.

\begin{abstract}
The present text of the Constitution of the Portuguese Republic adds under the same legal norm (art. 21) various forms of constitutional resistance. This article, from a historical perspective, will recover some of the manifold forms of manifestation of the right of resistance in Portugal, $v$. g., self-defense, the right of popular resistance and the right of individual resistance. The first objective is, not being advisable a watertight separation, to contribute to a possible differentiation between each of these forms. The second objective of this work is to counter the thesis that the right of popular resistance has been transformed, by modern constitutionalism, into an individual right of resistance to defend the fundamental rights enshrined in the Constitution. In this way, the historical element could be a contribution to the interpretation of the referred constitutional precept on the right of resistance.
\end{abstract}

Palavras chave: Direito de Resistência, Legítima Defesa, Proto Constitucionalismo, Portugal.

Key Words: Right to Resist, Self-defense, Proto Constitutionalism, Portugal. 


\section{INTRODUÇÃO ${ }^{1}$.}

Os vestígios de um típico direito de resistência universal são constante e assiduamente recuados à Idade Antiga: no Ocidente à Grécia de Sófocles ${ }^{2}$ e no Oriente à China de Confúcio e Mécio ${ }^{3}$. Tendo sido ao longo de muitos séculos o palco de interesse e debate entre os mais conceituados juristas, legistas, canonistas, teólogos, politólogos, estadistas, etc., vindo a contagiar de forma indelével os "American Founders", acabaria por assegurar e evidenciar até à hodiernidade o seu papel no seio da Teoria e da História Constitucional. Na verdade, o tema da resistência constitucional continua latejante e arrebatador para o pensamento constitucional, tanto ao nivel do ius como da praxis, da norma como do facto ou da razão como da vontade. Assim, acabou por se converter num atrativo de dois gumes: (i) para o historiador do Direito Constitucional, $v$. g., pelo seu lastro encanecido por mais de duas dezenas de séculos; (ii) para qualquer jurisperito mais voltado para a atualidade constitucional, v.g., pelo crescente de importância verificado nos últimos tempos, sobretudo a partir da segunda metade do século passado ${ }^{4}$, que levou à sua consagração em mais de $20 \%$ dos textos constitucionais vigentes que se encontram disseminados por cerca de quarenta e quatro Estados do mundo atual 5 .

Este artigo cingir-se-á, particularmente, em torno da índole historicista, num excursus relâmpago que vai desde a Baixa Idade Média até à Época Contemporânea, e, sobretudo, dentro do espaço geográfico que Portugal ocupou

1 Abreviaturas utilizadas: e. g. = exempli gratia (por exemplo) ou v. g. = verbi gratia (por exemplo); i.e. $=$ id est (isto é); OA = Ordenaçoens de El-Rey D. Affonso $V$, Coimbra, Imprensa da Universidade, 1792 (edição fac-simile da Fundação Calouste Gulbenkian, 1984/1998) [Disponível em http://www1.ci.uc.pt/ihti/proj/afonsinas/ (consultado a 15 de Janeiro de 2017)]; Dig. = Digesta e Cód. = Codex Iustinianus, Corpus Iuris Civilis, Paul Kruger e Theodor Mommsen (ed.), 1872-1895.

2 Mario TurchetTI, Tyrannie et Tyrannicide de l'Antiquité à nos Jours, Bibliothèque de la Renaissance 11, Paris, 2013; Rosana GALlo, La Tirania en la Antigua Grecia. Repercusiones en el Derecho Mercantil y Económico, Buenos Aires, Dunken, 2014.

3 Tom Ginsburg, Daniel LAnsberg-Rodriguez e Mila Versteeg, "When to Overthrow your Government: The Right to Resist in the World's Constitutions", in UCLA Law Review 60, 2013 , pp. 1195-1207 [Disponivel em: http://chicagounbound.uchicago.edu/cgi/viewcontent.cgi?article= 5102\&context=journal_articles (consultado a 30 de Agosto de 2016)].

4 Tom Ginsburg, Daniel Lansberg-Rodriguez e Mila Versteeg, "When to Overthrow your Government: The Right to Resist in the World's Constitutions", op. cit., pp. 1217-1220: "For over a century, a mere 5 percent of all constitutions included the right to resist. It is only in the second part of the twentieth century that the right to resist began to spread more widely, to about 10 percent in the 1980s and about 20 percent today. In April of 2012, Hungary became the latest nation to adopt the right to resist".

5 Tom Ginsburg, Daniel Lansberg-Rodriguez e Mila Versteeg, "When to Overthrow your Government: The Right to Resist in the World's Constitutions”, op. cit., pp. 1242-1259. Ao rol apresentado pelos autores acresce, ainda, a Constituição da República Popular da China 1975, art. $55^{\circ}$ ("É um dever sagrado de todo cidadão de la República Popular da China defender a pátria e opor resistência à agressão"); e o preâmbulo da Constituição da República de Angola 2010 ("Destacando que a Constituição da República de Angola se filia e enquadra directamente na já longa e persistente luta do povo angolano, primeiro, para resistir à ocupação colonizadora, depois para conquistar a independência e a dignidade de um Estado soberano e, mais tarde, para edificar, em Angola, um Estado democrático de direito e uma sociedade justa”). 
durante esse lapso de tempo. Tal como proposto em título, ao longo de muitos séculos, o direito de resistência assumiu várias formas (polimorfismo constitucional), $v$. g., resistência negativa ou positiva, resistência individual ou coletiva, resistência ativa ou passiva, resistência defensiva ou agressiva, etc. ${ }^{6}$.

Ora se, por um lado, o instituto jusfundamental da resistência teve de evoluir -mister perene e constante que se impõe a qualquer segmento do Direitopara se adaptar às vicissitudes ditadas pela realidade constitucional do momento; por outro lado, tudo leva a crer que tenha sido uma evolução paulatina, ocorrida dentro dos parâmetros estabelecidos desde a gênese de cada uma das suas diversas formas jurídicas. Quero com isto dizer que, ao contrário do que pretende a maioria da doutrina constitucional portuguesa, em momento algum terá existido uma "metamorfose" do direito de resistência coletivo ou da comunidade politica para um direito de resistência individual adjudicado a cada um dos membros dessa comunidade ${ }^{7}$. Dito de outra forma -e avançando com o que será um dos objetivos fundamentais deste trabalho- faz pouco sentido defender que, o constitucionalismo moderno terá ressuscitado o direito medieval de resistência popular, transformando-o em direito de resistência individual, através duma positivação na Constituição escrita, e reduzindo-o a um mecanismo inorgânico de defesa dos direitos fundamentais.

Deixando o desenvolvimento desta questão de fundo para o corpo do trabalho, antes de mais, cumpre rever de forma rápida e sucinta o curto aparatus bibliográfico português dedicado ao tema. No final da década de oitenta, o status quaestionis ressuma das versadas palavras de Margarida Cordeiro Mesquita: "Apesar de, desde muito cedo, ter sido objecto de reflexão na doutrina teológica, juridica e politica portuguesa e não obstante uma larga tradição ao nivel da sua recepção constitucional, a temática do direito de resistência não mereceu, neste século, entre nós, senão breves referências por parte de constitucionalistas $e$ penalistas". Entre as anteriores referências de maior vulto não se podem esquecer os excelsos contributos de jurishistoriadores como, v. g., Paulo Mêrea ${ }^{9}$,

6 Cf. José Joaquim Gomes CANOTIlHo e Vital Moreira, Constituição da República Portuguesa Anotada I, reimpressão da $4 .^{a}$ edição revista, Coimbra, Coimbra Editora, 2014, p. 421; Ermanno Vitale, Defenderse del Poder. Por una resistencia constitucional, Traducción de Pedro Salazar Ugarte y Paula Sofia Vásquez Sánchez, Madrid, Editorial Trotta, 2012, pp. 111-134; Marcello Caetano, Manual de Ciência Politica e Direito Constitucional I, $4 .^{a}$ reimpressão da 6 . $^{a}$ edição revista e atualizada por Miguel Galvão Teles, Coimbra, Almedina, 2010, p. 326; Jorge MiRANDA e Rui Medeiros, Constituição Portuguesa Anotada I, 2. ${ }^{a}$ edição, Coimbra, Coimbra Editora, 2010, p. 462; Maria Margarida Cordeiro MesquiTA, "Resistência (direito de)", in Dicionário Jurídico da Administração Pública, 1. ${ }^{\circ}$ Suplemento, Lisboa, 1998, pp. 428-430.

\footnotetext{
7 Nas laudas que se seguem, por uma questão de coerência com o fio condutor do trabalho, adota-se esta classificação bipartida, deixando as outras tipologias a cargo da bibliografia citada na nota de rodapé anterior.

8 Maria Margarida Cordeiro MesquitA, Direito de Resistência e Ordem Jurídica Portuguesa, Cadernos de Ciência e Técnica Fiscal (160), Lisboa, Centro de Estudos Fiscais, 1989, p. 7.

9 Paulo MerêA, Sobre a origem do poder civil: Estudos sobre o pensamento politico e jurídico dos séculos XVI e XVII, com Introdução e selecção de Miguel Nogueira de Brito e fixação e organização do texto de José Manuel Merêa Pizarro Beleza, Coimbra, Tenacitas, 2003, pp. 94-100. [Republicação dos textos seguintes: "Suárez, jurista. O problema da origem do poder civil" (1. ${ }^{a}$ edição, 1917); “A Ideia da Origem Popular do Poder nos Escritores Portugueses anteriores à Restauração" (1. a edição, 1923); "Suárez, Grócio e Hobbes" (1. a edição, 1941); e "Escolástica e Jusnaturalismo: o problema da origem do poder civil em Suárez e em Pufendorf” (1. a edição, 1943)].
} 
Marcelo Caetano ${ }^{10}$ e Martim de Albuquerque ${ }^{11}$. Para uma época posterior, Pedro Barbas Homem consigna uma súmula a esta temática na sua tese de Doutoramento, acabando por concluir que, em Portugal, a rutura com a doutrina democrática do direito de resistência e do tiranicídio terá ocorrido no século das Luzes, sobretudo a partir da data de 1758, referindo como "obra paradigmática" a Dedução cronológica e analitica, da lavra de José de Seabra da Silva (1732-1813), e os contributos complementares de Pascoal José de Melo Freire (1738-1798) e Tomás António Gonzaga (1744-1810) ${ }^{12}$.

Pouco a pouco, esse aparatus bibliográfico em torno da resistência constitucional portuguesa vai-se compondo. A começar pelas entradas em dicionários da autoria de, v. g., Nuno Rogeiro ${ }^{13}$, Maria Margarida Cordeiro Mesquita $^{14}$ e Germano Marques da Silva e Luís Fábrica ${ }^{15}$; passando aos indispensáveis comentários tecidos ao respetivo artigo em Constituições comentadas, v. g., os comentários de Marnoco e Souza à Constituição de 1911 (art. $\left.37^{\circ}\right)^{16}$, bem como os comentários à Constituição de 1976 de José Joaquim Gomes Canotilho e Vital Moreira ${ }^{17}$ e Jorge Miranda e Rui Medeiros ${ }^{18}$; concluindose o percurso pelas fontes de índole mais geral com uma referência obrigatória à manualistica constitucional mais autorizada, v. g., Lopes Praça19, Marcello

10 Marcello Caetano, "A Doutrina Católica da Resistência à Opressão", in Nação Portuguesa: Revista de Filosofia Politica (série 4, tomo 1), 1926, pp. 410-419.

11 Martim de Albuquerque, O Poder Politico no Renascimento Português, Lisboa, Verbo, 2012, pp. 265-292 (1. ${ }^{a}$ edição, Lisboa, Instituto Superior de Ciências Sociais e Politicas Ultramarinas, 1968).

12 António Pedro Barbas Homem, Judex Perfectus: Função Jurisdicional e Estatuto Judicial em Portugal 1640-1820, Coimbra, Almedina, 2003, pp. 145-155.

13 Nuno RogeIRo, (1983): "Resistência (direito de)", in Polis V, Lisboa, 1983, cols. 450-462

14 Maria Margarida Cordeiro Mesquita, "Resistência (direito de)", in Dicionário Jurídico da Administração Pública, 1. ${ }^{\circ}$ Suplemento, Lisboa, 1998, pp. 425-437.

15 Germano Marques da Silva, e Luís FÁBRICA, "Resistência (direito de)", in Verbo 25, Lisboa, 2002, cols. 238-242.

16 José Ferreira Marnoco e SouzA, Constituição Politica da República Portuguesa, Comentário, Lisboa, Imprensa Nacional-Casa da Moeda, 2011, pp. 156-157 (1. a edição, Coimbra, 1913).

17 José Joaquim Gomes CANotilho e Vital MoreirA, Constituição da República Portuguesa Anotada I, op. cit., pp. 420-422.

18 Jorge Miranda e Rui Medeiros, Constituição Portuguesa Anotada I, op. cit., pp. 457-467.

19 José Joaquim Lopes PRAÇA, Direito Constitucional Portuguez I, Coimbra Editora, 1977, pp. 124-133 (1. ${ }^{a}$ edição, Coimbra, 1878). 
Caetano $^{20}$, Gomes Canotilho ${ }^{21}$, Jorge Miranda ${ }^{22}$, Bacelar Gouveia ${ }^{23}$, Vieira de Andrade $^{24}$ e Melo Alexandrino ${ }^{25}$.

A nivel de estudos monográficos -que são os que verdadeiramente aportam destacadas inovações científicas-, no ano de 1984/85 foi apresentada à Faculdade de Direito de Lisboa a tese de mestrado intitulada " $A$ Constitucionalização do Direito de Resistência", da lavra de Assunção Esteves ${ }^{26}$. Margarida Mesquita, após a obra supra referida, publicada no mesmo ano de 1989, voltou ao tema com mais um excelente contributo dedicado ao "Direito de Resistência e Ordem Fiscal: Reflexões sobre o artigo $106^{\circ}, n .^{\circ} 3$ da Constituição da República Portuguesa'27. Recentemente, cingindo-se ao século XVII, do punho de Pedro Calafate veio a lume o estudo "Da Origem Popular do Poder ao Direito de Resistência, Doutrinas Politicas no Século XVII em Portugal'28.

Apesar de todas estas achegas, continua a faltar um estudo de fundo que abarque o direito de resistência desde o dealbar da monarquia lusa até à CRP de 1976. O direito de resistência foi a trave mestra do pensamento constitucional da Idade Média, que viria a ser particularmente preservado na Península Ibérica pela pena dos autores da segunda escolástica (escolástica ibérica, neoescolástica peninsular, escola de Salamanca, etc.). O que fez com que em Portugal, a partir de meados do século XVIII, a ideia de uma resistência política contra o poder monárquico viesse a ser ferozmente combatida e os seus sequazes acusados de monarcómacos -em referência depreciativa à corrente proto-liberal europeia encabeçada por teóricos quinhentistas como François Hotman, Teodoro de Beza, Junius Brutus, George Buchanan, etc.--

O constitucionalismo revolucionário moderno, em princípio e de uma forma geral, não aderiu de imediato à sua positivação nos códigos constitucionais escritos, contribuindo solenemente para um certo eclipse da resistência

20 Marcello Caetano, Manual de Ciência Politica e Direito Constitucional I, op. cit., pp. 326-329 (as primeiras lições são de 1952).

21 José Joaquim Gomes CANotilho, Direito Constitucional e Teoria da Constituição, reimpressão

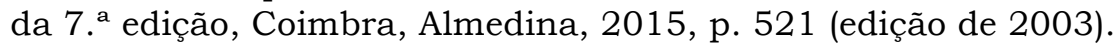

22 Jorge MiRAndA, Manual de Direito Constitucional IV - Direitos Fundamentais, Coimbra, Coimbra Editora, 2014, pp. 449-457.

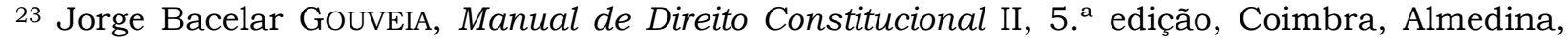
2013, pp. 1031-1033.

24 José Carlos Vieira de AndRADE, Os Direitos Fundamentais na Constituição Portuguesa de 1976, 5. ${ }^{a}$ edição, Coimbra, Almedina, 2012, pp. 340-341.

25 José de Melo Alexandrino, Direitos Fundamentais - Introdução geral, 2. ${ }^{\text {a }}$ edição, Estoril, Principia, 2011, pp. 108-110.

26 Maria da Assunção Andrade Esteves, A Constitucionalização do Direito de Resistência, Dissertação apresentada no curso de mestrado da Faculdade de Direito de Lisboa do ano lectivo de 1984/85, Lisboa, Associação Académica da Faculdade de Direito de Lisboa, 1989.

27 Maria Margarida Cordeiro Mesquita, Direito de Resistência e Ordem Fiscal: Reflexões sobre o artigo $106^{\circ}$, n. ${ }^{\circ} 3$ da Constituição da República Portuguesa, Coimbra, 1996.

28 Pedro Calafate, Da Origem Popular do Poder ao Direito de Resistência, Doutrinas Politicas no Século XVII em Portugal, Lisboa, Esfera do Caos, 2012. 
constitucional até meados do século $\mathrm{XX}^{29}$. Mesmo assim, entre nós, ainda se descobrem sapientes publicistas que, no advento do constitucionalismo luso, lhe dispensaram abordagem conscienciosa, v. g., Almeida Garrett (1799-1854) ${ }^{30} \mathrm{e}$ Silvestre Pinheiro Ferreira (1769-1846) ${ }^{31}$.

Após esta muito rápida e sumaríssima incursão pelo status quaestionis do direito de resistência em Portugal, vamos entrar no objeto imediato proposto para este estudo: o polimorfismo inerente ao artigo $21^{\circ}$ (Direito de resistência) da CRP. Nesta tarefa, dividida em duas partes (polimorfismo do artigo $21^{\circ}$ e polimorfismo do direito de resistência), vai-se tentar dissecar o conteúdo deste fragmento da CRP, no intuito de identificar e diferenciar os diversos institutos jurídicos que lhe são intrínsecos e, por esta via, trazer à colação a tese formada em torno da "metamorfose" do direito de resistência, acarretada pelo processo da sua constitucionalização ou positivação no código constitucional. A seguir a cada uma dessas fases, desfia-se o punhado de escassos subsídios históricos escritos que foi possivel coligir, contribuindo para o estudo pré-constitucional das diferentes formas de resistência constitucional. Por este meio, entendemos ser possivel certificar a coexistência, lado a lado, ao longo de vários séculos e até à atualidade, da resistência coletiva com a resistência individual. Se assim se entender e ficar patente, abre-se o caminho demonstrativo do erro em que caiu a tese defensora de uma plausivel "metamorfose" do direito de resistência, ou seja, de uma resistência coletiva para uma resistência individual.

\section{POLIMORFISMO DO ARTIGO $21^{\circ}$ DA CRP.}

Uma primeira manifestação de polimorfismo no atual artigo $21^{\circ}$ da CRP é facilmente detetável a partir do seu elemento literal, na medida em que a todos é garantido um direito de resistência $\left(1 .^{a}\right.$ parte do preceito: "direito de resistir a qualquer ordem que ofenda os seus direitos, liberdades e garantias') e um direito à legítima defesa -e ação direta ${ }^{32}-\left(2 .^{a}\right.$ parte do preceito: "[direito] de repelir pela força qualquer agressão, quando não seja possivel recorrer à autoridade pública"). Direito de resistência e legitima defesa são, assim, as duas formas distintas de resistência constitucional explicitamente previstas no artigo $21^{\circ}$ da CRP.

Trata-se de dois institutos jurídicos de cariz jusfundamental muito próximos, que partilham a mesma ratio iuris da autodefesa ou autotutela. " $O$ direito de resistência -asseveram Gomes Canotilho e Vital Moreira- vale não apenas perante os poderes públicos, mas também nas relações particulares. Pode-

29 Juan Ignacio UGARTEMEndíA ECEIZABARRENA, “El derecho de Resistencia y su 'Constitucionalización"', in Revista de Estudios Políticos 103, 1999, pp. 222-245 [Disponivel em: http://dialnet.unirioja.es/servlet/articulo?codigo=27541 (consultado a 1 de Setembro de 2016)]; Mario TURChETTI, Tyrannie et Tyrannicide de l'Antiquité à nos Jours, op. cit., pp. 949-970.

30 Almeida GARRETT, O Dia Vinte e Quatro de Agosto, Lisboa, Tipographia Rollandiana, 1821, pp. 26-31 [Disponivel em: http://purl.pt/51 (consultado a 1 de Setembro de 2016)].

31 Susana Antas VIDEIRA, Para a História do Direito Constitucional Português: Silvestre Pinheiro Ferreira, Coimbra, Almedina, 2005, pp. 225-244.

32 Cf. Ac. 337/99 do Tribunal Constitucional. Jorge Miranda ainda considera um problema a encarar, embora entenda não ser de excluir a ação direta, em algumas circunstâncias, para tutela de direitos fundamentais - Jorge MIRANDA, Manual de Direito Constitucional IV - Direitos Fundamentais, op. cit., p. 457. 
se resistir tanto à ordem de uma autoridade policial (que ilegitimamente restringe, por ex., a liberdade de deslocação), como à ordem de uma entidade patronal (que ilegitimamente ordene a expulsão de um trabalhador do seu posto de trabalho); tanto se pode resistir à agressão física ou à invasão do domicílio perpetrada por um particular como por qualquer autoridade"33. Fernanda Palma, por seu turno, a partir do binómio defesa de direitos e defesa da ordem democrática, admite que "o alargamento do direito de resistência a formas activas de desobediência e à defesa contra os particulares significa, forçosamente, que a defesa da ordem e a defesa dos direitos se fundem, de modo que a segunda se erige como a razão de ser da primeira, ou até que o problema das relações entre elas não existe, porque ambas se convertem numa única figura jurídica. A problemática do direito de resistência corre por águas idênticas às da fundamentação da legítima defesa, não existindo autonomia material entre as duas questões, se bem que, formalmente, sejam tratadas em diferentes locais do ordenamento juridico" ${ }^{34}$. O que nada obsta, antes pelo contrário, que possam e devam ser diferenciados -pela legislação ordinária, pela doutrina e pela jurisprudência- nos seus contornos materiais de aplicação prática ${ }^{35}$.

Em relação à afinidade entre estes dois mecanismos de autotutela, é de salientar a partilha cumulativa de, pelo menos, três pressupostos essenciais:

(i) Ajuridicidade - Ambos pressupõem um exercício fora do quadro normativo vigente, funcionando como causa especial de justificação da ilicitude, ilegalidade ou inconstitucionalidade;

(ii) Subsidiariedade - A sua legitimidade e legalidade pressupõe uma ultima ratio, i. e., o recurso a qualquer um dos direitos (resistência ou legítima defesa) só é admissivel quando se tenham esgotado ou não seja possivel o recurso aos mecanismos de tutela pública ou de Direito positivo;

(iii) Proporcionalidade - O seu exercício não dispensa o respeito pelas três dimensões do principio da proporcionalidade: necessidade, adequação e racionalidade ou proporcionalidade stricto sensu (art. $18^{\circ}$, n. ${ }^{\circ} 2$ da CRP).

Seria demasiado ocioso estar a entrar aqui em pormenores, sendo que para os propósitos deste estudo basta deixar patente que o direito de resistência pressupõe uma manifestação de força contra o poder político e a legítima defesa uma manifestação de força entre privados. A cisão do preceituado no artigo $21^{\circ}$ da CRP em duas partes e respetiva diferenciação ficam cingidas, praticamente, à qualidade (pública ou privada) do sujeito contra o qual se exerça a força defensiva, no sentido de se fazer justiça e tutelar direitos e liberdades

33 José Joaquim Gomes CANOTILHo e Vital Moreira, Constituição da República Portuguesa Anotada I, op. cit., pp. 420-421. Não será despiciendo que a Constituição do Equador 2008 no seu articulado (art. 98 ${ }^{\circ}$ ) venha estabelecer, expressamente, um direito de resistência contra o "poder público" ou contra "pessoas naturais ou juridicas não estatais"

34 Maria Fernanda Palma, A Justificação por Legitima Defesa como Problema de Limitação de Direitos I, Lisboa, 1990, pp. 222-223.

35 Maria Margarida Cordeiro Mesquita, Direito de Resistência e Ordem Jurídica Portuguesa, op. cit., p. 35, nota 72 e Maria Margarida Cordeiro MEsquiTA, Direito de Resistência e Ordem Fiscal, op. cit., p. 65, nota 124 . 
fundamentais ${ }^{36}$. A Constituinte de Timor Leste (2002) resolve a questão com mestria: ampliando a epígrafe e dividindo o artigo em dois números, adjudicando um número ao direito de resistência e o outro número à legítima defesa (que remete para a lei ordinária) ${ }^{37}$.

Em Portugal, a formalização da legitima defesa no texto constitucional ocorre a partir da Constituição de 1933 (art. $8^{\circ}$, n. ${ }^{\circ} 19$ da C.1933), que a veio anexar ao direito de resistência oriundo da Constituição anterior de 1911. A partir de então, os dois direitos-garantia mantiveram-se sempre acoplados sob a égide da mesma cláusula constitucional: quer no texto originário de 1976 (art. $20^{\circ}, \mathrm{n} .{ }^{\circ} 2$ da CRP), quer após a primeira revisão constitucional de 1982 (art. $21^{\circ}$ da CRP). No entanto, "não distinguir os dois direitos -assevera Margarida Mesquita- é esquecer os fundamentos, a história e o significado que ainda hoje assume o direito de resistência" 38 .

Hoje, o Estado de Direito pressupõe um Estado de justiça pública, cabendo aos tribunais a competência para administrar a justiça em nome do povo (art. $202^{\circ}{ }$ n. ${ }^{\circ} 1$ da CRP); e proibindo-se, expressamente, quaisquer instrumentos e formas de justiça privada ou autotutela não institucionalizados por lei (art. $202^{\circ}$, n. ${ }^{\circ} 4$ da CRP). A legítima defesa ainda se mantêm entre os instrumentos de autotutela institucionalizados por lei, mas, como veremos de seguida, os seus primórdios legislativos lusos podem ser recuados até ao dealbar da monarquia portuguesa na Baixa Idade Média ${ }^{39}$.

\section{A LINHAGEM PRÉ-CONSTITUCIONAL DA LEGÍTIMA DEFESA.}

A legítima defesa entronca na vingança, como forma primordial de repressão criminal exercida por todos os povos tribais e primitivos, em que o ofendido, por decisão própria, retribui o mal sofrido com outro mal idêntico. Posteriormente,

36 Marcello Caetano, Manual de Ciência Politica e Direito Constitucional I, op. cit., p. 327; José Carlos Vieira de ANDRADE, Os Direitos Fundamentais na Constituição Portuguesa de 1976, op. cit., pp. 340-341; Jorge MIRANDA, Manual de Direito Constitucional IV - Direitos Fundamentais, op. cit., p.455, n. 2; Jorge MirandA e Rui MEdeIRos, Constituição Portuguesa Anotada I, op. cit., pp. 464465; Maria da Assunção Andrade Esteves, A Constitucionalização do Direito de Resistência, op. cit., pp. 209-221; Maria Margarida Cordeiro MEsquiTA, Direito de Resistência e Ordem Jurídica Portuguesa, op. cit., pp. 34-35; Maria Margarida Cordeiro MESQUITA, Direito de Resistência e Ordem Fiscal, op. cit., pp. 60 e 65 (cf. os criminalistas que partilham da mesma opinião referidos na nota 113); Maria Margarida Cordeiro MesquitA, "Resistência (direito de)", op. cit., p. 435.

37 Constituição da República Democrática de Timor-Leste de 2002: "artigo $28^{\circ}$ (Direito de resistência e legitima defesa): 1. Todos os cidadãos têm o direito de não acatar e de resistir às ordens ilegais ou que ofendam os seus direitos, liberdades e garantias fundamentais. 2. A todos é garantido o direito de legítima defesa, nos termos da lei".

38 Maria Margarida Cordeiro MEsQuita, "Resistência (direito de)”, op. cit., p. 435.

39 Sobre a legitima defesa, cf. David B. Kopel, Paul GAllant e Joanne D. Eisen, "The Human Right of Self-Defense", in Brigham Young University Journal of Public Law 22/1, 2007, pp. 43-178 [Disponivel em: http://digitalcommons.law. byu.edu/jpl/vol22/iss $1 / 3$ (consultado a 3 de Setembro de 2016)]; Thierry KouAmé, "Légitime défense du corps et légitime défense des biens chez les Glossateurs (XIIe-XIIIe siècle)", in Violences Souveraines au Moyen Âge. Travaux d'une école historique, ed. François Foronda, C. Barralis e B. Sère, Paris, Presses Universitaires de France, 2010, pp. 19-27; Charles J. REID, "The Rights of Self-Defense and Justified Warfare in the Writings of the Twelfth and Thirteenth Century Canonists", in Law as Profession and Practice in Medieval Europe: Essays in Honor of James A. Brundage, Ashgate, 2011, pp. 73-92. 
esta ideia de pura vingança de sangue vai evoluir para uma forma ainda arcaica de justiça privada ou vindicta privada, que já pressupõe a mediação de uma entidade judiciária (o concelho ou o juiz), antes de o ofendido ou a comunidade poderem exercer o seu direito de retaliação contra o criminoso. O período da Idade Média portuguesa caracteriza-se por uma acesa lide do poder político monárquico contra diversas manifestações de vindicta privada, iniciada pela atividade legiferante de D. Afonso II (Lei de 1211$)^{40}$ e prosseguida nos reinados de D. Dinis (Leis de $1303^{41}, 1305^{42}$ e $1318^{43}$ ) e do seu filho D. Afonso IV (Leis de $1325^{44}, 1326^{45}$ e $\left.1347^{46}\right)$.

No âmbito do Ius commune medieval o direito de legítima defesa extrajudicial gozava de um reconhecimento universal e fazia parte do Direito natural, tal como ficou expresso em consilium de circa 1312, da autoria de Oldradus de Ponte ${ }^{47}$. No ordenamento luso, por seu turno, as mais recuadas menções à legítima defesa assomam a partir do direito foralengo, $v$. g., no foral de Penamacor, outorgado em 1209 por D. Sancho I, iliba-se de qualquer sanção o homicida que tenha agido em defesa do seu corpo -"Et si pro iusticia aliquis fuerit occisus nichil pectent pro eo" (E

40 Alexandre Herculano, Portugaliae Monumenta Historica: A saeculo octavo post christum usque ad quintumdecimum - Leges et Consuetudines I, Lisboa, Academia das Ciências, 1866, p. 171; Livro das Leis e Posturas, Prefácio de Nuno Espinosa Gomes da Silva e leitura paleográfica e transcrição de Maria Teresa Campos RodRigues, Lisboa, 1971, pp. 14-15; Ordenações de D. Duarte, Edição preparada por Martim de AlBuquerque e Eduardo Borges Nunes, Lisboa, 1988, pp. 48-49; José Artur Duarte NogueirA, Lei e Poder Régio I: As Leis de Afonso II, Lisboa, 2006, pp. 425-427.

41 Livro das Leis e Posturas, Prefácio de Nuno Espinosa Gomes da Silva e leitura paleográfica e transcrição de Maria Teresa Campos RodRIGUes, Lisboa, 1971, pp. 80-81; Ordenações de D. Duarte, Edição preparada por Martim de AlBuquerque e Eduardo Borges NunEs, Lisboa, 1988, p. 189; Ordenaçoens de El-Rey D. Affonso V, Coimbra, Imprensa da Universidade, 1792, Liv. V, Tít. 73 (edição fac-simile da Fundação Calouste Gulbenkian, 1984/1998); José DominguEs, As Ordenações Afonsinas: Três Séculos de Direito Medieval (1211-1521), Sintra, 2008, pp. 441-442.

42 Livro das Leis e Posturas, Prefácio de Nuno Espinosa Gomes da Silva e leitura paleográfica e transcrição de Maria Teresa Campos RodRIGues, Lisboa, 1971, p. 81; Ordenações de D. Duarte, Edição preparada por Martim de AlBuQUERQUe e Eduardo Borges NunES, Lisboa, 1988, p. 189.

43 Livro das Leis e Posturas, Prefácio de Nuno Espinosa Gomes da SiLVA e leitura paleográfica e transcrição de Maria Teresa Campos RodRIGUes, Lisboa, 1971, pp. 190-191; Ordenações de D. Duarte, Edição preparada por Martim de AlBuQUERQUe e Eduardo Borges NunEs, Lisboa, 1988, p. 303.

44 Ordenações de D. Duarte, Edição preparada por Martim de AlBuQuerque e Eduardo Borges NunEs, Lisboa, 1988, pp. 373-376.

45 Livro das Leis e Posturas, Prefácio de Nuno Espinosa Gomes da SiLVA e leitura paleográfica e transcrição de Maria Teresa Campos RodRIGUES, Lisboa, 1971, pp. 285-286; Ordenações de D. Duarte, Edição preparada por Martim de AlBuQuerque e Eduardo Borges NunES, Lisboa, 1988, pp. 378-380; Ordenaçoens de El-Rey D. Affonso V, Coimbra, Imprensa da Universidade, 1792, Liv. V, Tít. 53, §§ 1-11 (edição fac-simile da Fundação Calouste Gulbenkian, 1984/1998).

46 Livro das Leis e Posturas, Prefácio de Nuno Espinosa Gomes da SiLVA e leitura paleográfica e transcrição de Maria Teresa Campos RodRIGUes, Lisboa, 1971, pp. 414-417; Ordenações de D. Duarte, Edição preparada por Martim de AlBuQuerque e Eduardo Borges Nunes, Lisboa, 1988, pp. 388-392; Ordenaçoens de El-Rey D. Affonso V, Coimbra, Imprensa da Universidade, 1792, Liv. V, Tít. 53, §§ 13-24 (edição fac-simile da Fundação Calouste Gulbenkian, 1984/1998).

47 Kenneth Pennington, "Politics in Western Jurisprudence", in A Treatise of Legal Philosophy and General Jurisprudence 7: The Jurists' Philosophy of Law from Rome to the Seventeenth Century, edd. Andrea Padovani e Peter G. Stein, Dordrecht, Springer, 2007, p. 196. 
se alguém for morto em legítima defesa nada paguem por ele)- bem como o que tenha atuado em defesa da sua casa e do seu património -"Siquis ad uestras uillas uenerit accipere cibos, aut aliquam rem per forciam et ibi mortuus fuerit, aut percussus, non pectent pro illis, neque sint homicide de suis parentibus" (Se alguém vier às vossas habitações tomar pela força víveres ou outra coisa qualquer e aí for morto ou ferido, não paguem por ele, nem sejam considerados homicidas pelos parentes dele)-48.

Para o período medieval português ainda não se conhece nenhuma lei geral com uma formulação explícita e sistemática para a legítima defesa, não obstante os vários testemunhos legislativos tácitos que se possam garimpar ${ }^{49}$. Um primeiro testemunho credivel do passado histórico da legitima defesa surge em apontamento legislativo do século XIII, tributado ao reinado de D. Afonso III (1245-1279). Alicerçado no fragmento "vim vi repellere licet" do Digesto (Dig. 43.16.1.27) ${ }^{50}$, o fragmento afonsino legitima o recurso à força e à violência para obstar a um esbulho violento da posse ${ }^{51}$. Trata-se, nesta conjuntura, de uma defesa do património do próprio agente ${ }^{52}$.

Mas a legítima defesa visa, também e sobretudo, a proteção da integridade física das pessoas ${ }^{53}$. O princípio da legitima defesa para salvaguarda da vida e da integridade física surge reconhecido em vários preceitos do primeiros monarcas lusos: em lei de D. Dinis de 1303, que ressalva os homicídios e agressões perpetrados contra a paz da casa, da propriedade e do caminho (OA 5.73) ${ }^{54}$; em

48 Alexandre Herculano, Portugaliae Monumenta Historica: A saeculo octavo post christum usque ad quintumdecimum - Leges et Consuetudines I-4, Lisboa, Academia das Ciências, 1864, pp. 539540 .

49 Ao contrário do que acontecia em Castela, v. g., nas Partidas e no Foro Real de Afonso X José María GARCía MARín, "La legítima defensa hasta fines de la Edad Media", in Anuario de Historia del Derecho Español 50, 1980, pp. 434-438 [Disponivel em: http://www.boe.es/publicaciones/anuarios_derecho/articulo.php?id=ANU-H-1980-10041300438 (consultado a 3 de Setembro de 2016)]- onde também se manteve em vigor o preceituado no Liber Iudicum, romanceado para Fuero Juzgo -José María GARCíA MARÍN, "La legítima defensa hasta fines de la Edad Media", op. cit., pp. 420-425-.

50 "Vim vi repellere licere Cassius scribit, idque ius natura comparatur; apparet autem, inquit, ex eo, arma armis repellere licere" (Escreveu Cassio que é lícito repelir a força com a força, e que este direito se adquire pela natureza; e isto resulta, diz, de que é licito repelir as armas com as armas). Sobre a legítima defesa no Direito Romano, $c f$. José María GARCíA MARÍN, "La legítima defensa hasta fines de la Edad Media”, op. cit., pp. 415-420.

51 Em outro fragmento do Código de Justiniano (Cód. 8.4.1) consta: "Recte possidenti ad defendendam possessionem quam sine vitio tenebat, inculpatae tutelae moderatione illatam vim propulsare licet" (Ao que possui legitimamente, para defender a posse que tinha sem vício, é licito responder com a força, mas com a moderação de uma defesa justificável).

52 ODD (1988), pp. 110-111: "Estabelecido he que se alguum filhar a outro por força e per sa autoridade alguma cousa que tever ou de que estever em posse perca o direito que ouver em ella e se em ella direito nom ouver torne-lhe aquella cousa que lhe assy tomou com outro tanto do seu proprio salvo em aquelles casos em que o direito diz vim vi repelere licet. Que quer dizer: força per força se tolheo". A restituição em dobro, em caso de tomada de posse violenta, já vinha estabelecida em normativo das Cortes de Leão de 1188 (art. 10).

53 Thierry Kounmé, "Légitime défense du corps et légitime défense des biens chez les Glossateurs (XIIe-XIIIe siècle)", op. cit., pp. 19-27.

54 "todos aquelles que forem a casa d'alguum ou pousada ou a seu herdamento ou a terra que tenha de Senhor ou a prestemo que tenha d'alguem ou emprazamento que tenha de quem quer ou a 
lei de D. Afonso IV de 1325, contra a justiça privada55; num capitulo geral das Cortes de Santarém de 1331, os procuradores do povo apresentam queixa contra os mordomos e alcaides que levavam coimas dos que tiravam armas "em defendimento dos seus corpos", respondendo o monarca que a legítima defesa é um direito natural de cada um (OA 5.74) ${ }^{56}$; e em lei de D. João I como justificação do que mata ou fere na Corte "em defendimento do seu corpo e da sua vida" (OA 5.33.6) ${ }^{57}$. Acresce ainda um fugaz e lacónico comentário do punho do compilador das Ordenações de D. Afonso V (1446), a propósito da carta de segurança outorgada aquele que, pretendendo responder e defender-se perante a Justiça em liberdade, confessa ter praticado o "maleficio", mas alega em sua defesa "que ofez em defendimento do seu corpo"58.

Nestes tempos longínquos existe outra forma de legitima defesa, que é exercida para salvaguarda da honra, $v$. g., em caso de adultério. Uma Lei dionisina de 11 de Setembro de 1302 estabelece a pena de morte para a mulher e seu cúmplice (OA 5.12.1), em complemento do estatuído no título "do que dorme com molher casada per sua vontade" (OA 5.7). D. Dinis para obstar e controlar os eventuais abusos cometidos pelos maridos que matavam as mulheres alegando a prática de adultério, por Lei de 14 de Agosto de 1302, impôs às justiças que lho fizessem saber por carta cerrada e selada: "porque eu quero que a minha Justiça nom despereça em aquelles que as suas molheres matarem sem merecimento; outrosy quero que aquelles que a direito por tal rasom matarem nom ajam medo nem se catem de mim nem de minha Justiça" (OA 5.18.1). o monarca sucessor, D. Afonso IV, admitiu que o marido pudesse matar a mulher adúltera, mesmo fora de flagrante delito (OA 5.18.2). O mesmo título das Ordenações Afonsinas, com base nos costumes do reino, define as condições em que o marido pode matar o adúltero (OA 5.18.5-6). Este costume antigo do reino é ressalvado na lei contra a

caminho perque vaão pera o matar ou deshonrar ou pera the fazer e hi morrer el ou aquelles que com elle forem ou cada hum delles ou hy forem chagados ou deshonrados nom seja aquelle que se defender nem aquelles que com elle esteverem omiziam daquelles que o cometerem nem dos que com elle forem, nem de seu linhagem delles".

55 ODD, pp. 373-376: "vendo como poderia acontecer que alguns em defendimento de seu corpo ou por outra razão direita poderiam matar alguém, e estes poderiam e deviam ser quites da morte por justiça, havendo ai de vir tal quitação por sentença não seria de tal razão que onde a justiça que deve ser maior acoimador do que se sem razão fizer não achar lugar para acoimar com direito e haver de ficar acoimador sem justiça, então, seria desigual razão. Porque onde a justiça dá por quite aquele que faz morte com direito [não] haverá de ficar lugar para o matarem para acoimamento por morte, o que ele fez com direito".

$56 \mathrm{O}$ monarca respondeu que "aquelles que tirarem armas em defendimento de seus corpos e com ellas ferirem ou matarem nom levem delles pena nem coima por tal razom ca d'outra guisa seria contra direito e razom natural levarem cooima daquelle que nom he em culpa de tal feito nem se moveo pera fazer mal mais pera se remir e enparar ao que cada huum naturalmente he theudo".

57 Marcello Caetano, História do Direito Português (Sécs. XII-XVI), 4. ${ }^{a}$ edição, Lisboa e São Paulo, 2000, pp. 365-366 e p. 568; Maria Fernanda PALMA, A Justificação por Legítima Defesa como Problema de Limitação de Direitos I, op. cit., pp. 191-192, nota 1. Esta última autora identifica os respetivos títulos das Ordenações Manuelinas (OM 5.10), onde já aparece a "invocação clara do moderamen inculpatae tutelae”, e das Ordenações Filipinas (OF 5.35).

58 "porque toda cousa que homem faça em defendimento de seu Corpo, ainda que mate ou feira, toda he licita e premissa per Direito e ainda he jeralmente per todos louvada" (OA 3.123.3). 
vindicta privada (OA 5.53.26) ${ }^{59}$. Nos foros extensos medievais das vilas de RibaCôa (Alfaiates, Castelo Rodrigo, Castelo Bom e Castelo Mendo) também consta a possibilidade de o marido poder matar, de forma impune, a mulher adúltera e o seu cúmplice60.

Apesar de excessivamente parcos e muito sucintos, são referências suficientes que, desde os tempos primordiais de Portugal, colocam a legítima defesa a par com o político direito de resistência, sem que se confundam propriamente os contornos dos seus conceitos. Mas, para melhor compreensão, é inescusável passarmos à distinção dos dois tipos de resistência em causa: o direito de resistência do indivíduo e o direito de resistência do povo, ambos face ao poder público.

\section{POLIMORFISMO DO DIREITO DE RESISTÊNCIA NA CRP.}

Uma segunda manifestação do polimorfismo da resistência constitucional na CRP não é, prima facie, tão patente como a anterior, tornando indispensável a intervenção da doutrina constitucional. Em causa estão as duas tipologias elementares do direito de resistência -coletivo e individual- que se podem cruzar em determinados aspetos, mas sem se confundirem.

O direito de resistência do indivíduo é (tendencialmente) ${ }^{61}$ individual e subjetivo é um direito consagrado para defesa dos direitos fundamentais ou do "estatuto constitucional do individuo"62. É considerado um direito subjetivo análogo aos direitos, liberdades e garantias (art. $17^{\circ}$ da CRP) e, por isso mesmo, beneficiário do seu regime especial no que toca, $v . g$., à sua aplicabilidade direta e vinculação de entidades públicas e privadas (art. $18^{\circ}, \mathrm{n} .{ }^{\circ} 1$ da CRP), à reserva relativa de competência legislativa da Assembleia da República (al. b) do art. $165^{\circ}$, n. ${ }^{\circ} 1$ da CRP) e à garantia do direito à indemnização resultante de ações ou omissões públicas que o violem (art. $22^{\circ}$ da CRP) ${ }^{63}$.

59 "assy como se alguum achasse com sua mulher em adulterio honde lhe he outorgado per costume dos nossos Regnos que per sy meesmo possa tomar vingança da dita deshonra sem outra authoridade de Justiça”.

60 Maria Alice TAVAREs, Costumes e Foros de Riba-Côa - Normativa e Sociedade, Tese de Doutoramento em História Medieval, Universidade de Lisboa, 2014, pp. 101-102 [Disponivel em http:/ / hdl.handle.net/10451/11343 (consultado a 13 de Janeiro de 2017)].

61 Tendencialmente, por um lado, porque pode ser de exercício coletivo e, por outro lado, ao funcionar como garante de direitos fundamentais do indivíduo, também funcionará, em última instância, como garante da própria Constituição e da ordem constitucional.

62 Maria Margarida Cordeiro MesquiTA, "Resistência (direito de)", op. cit., p. 427.

63 Cf. José Carlos Vieira de AndRade, Os Direitos Fundamentais na Constituição Portuguesa de 1976, op. cit., p. 340; Maria Margarida Cordeiro Mesquita, Direito de Resistência e Ordem Juridica Portuguesa, op. cit., p. 32; Maria Margarida Cordeiro MEsQuITA, Direito de Resistência e Ordem Fiscal, op. cit., p. 62; Maria Margarida Cordeiro MEsQuiTA, "Resistência (direito de)", op. cit., p. 433; José de Melo AlexAndrino, Direitos Fundamentais - Introdução geral, op. cit., p. 109; e o Ac. 34/2012 do Tribunal Constitucional. Em sentido contrário, v. g., Juan Ignacio UGARTEMENDÍA ECEIZABARRENA, "El derecho de Resistencia y su 'Constitucionalización”, op. cit., p. 244: este autor entende que " $n i$ el derecho de resistencia (constitucional) colectiva ni la variante conocida como "individual o del particular" son o se configuran como un derecho en sentido estricto (legal right), al menos no como un derecho subjetivo autónomo, sino más bien, como una facultad o competencia de las personas ínsita en la propia dinámica del ejercicio legítimo de los derechos y en el reconocimiento de los principios constitucionales democráticos”. Germano Marques da SILVA, e Luís FÁBRICA, 
Diversamente, o direito de resistência coletivo ou popular é um direito objetivo que reconhece ao povo (ou aos seus representantes) o direito de se opor ativamente ao poder político arbitrário ou tirânico e às suas leis injustas, bem como ao jugo externo. Pelas suas antiquíssimas origens e pelo eminente interesse dispensado pela faraónica literatura dos mais variados quadrantes, que se encontra disseminada ao longo dos séculos, desde a Antiguidade até à Contemporaneidade, a resistência coletiva acabou por se converter no "direito de resistência" por excelência.

Importa, no entanto, não confundir estas duas formas constitucionais de resistir contra o poder arbitrário e despótico, mesmo que não seja possível separá-las de um golpe seco e em linha reta. Em sintese, podemos afirmar que o direito de resistência popular ou coletivo se diferencia por ser um direito de acentuado cariz: (i) Objetivo - para defesa do bem comum da comunidade politica ou então, a partir do constitucionalismo revolucionário, do bem jurídico ordem constitucional. O direito de resistência individual tem, como ficou dito, um caracter subjetivo de defesa de direitos fundamentais do próprio indivíduo. (ii) Coletivo - por, em princípio, ser exercido pela coletividade ou grupo representativo. Repito, "em princípio", porque ter-se-á em conta que o plausível exercício individual (por apenas um membro da comunidade política) desta resistência ou do tiranicídio já aparece em obras dos escolásticos ibéricos $-v$. $g$., Controversias Mustres (1564) de Fernando Vásquez de Menchaca64 e De Regi et Regis Institutione (1599) de Juan de Mariana65- e dos primeiros monarcómacos v. g., La Gaule Françoise (1573) de François Hotman ${ }^{66}$, Vindiciae Contra Tyrannos (1579) de Junius Brutus (pseudónimo)67 e De Jure Regni (1579) de George Buchanan ${ }^{68}$ - E, ao invés, também a resistência individual pode ser levada a cabo por um conjunto vasto e indeterminado de pessoas, $i$. e, "o direito de resistência para defesa de direitos constitucionais tanto pode ser de exercício individual como colectivo"69.

A esmagadora maioria da doutrina constitucional inclina-se para uma leitura do artigo $21^{\circ}$ da CRP como uma resistência individual de defesa de direitos e liberdades constitucionais $-v$. g., nas doutas palavras de Gomes Canotilho, "pela redacção do artigo $21^{\circ}$ deduz-se que não está aqui em causa o

\footnotetext{
"Resistência (direito de)", op. cit., col. 241, também apontam para um direito de resistência "não tanto como um direito em si quanto como uma garantia (subsidiária) de outros direitos".

64 Fernando VÁZQUez de MenchaCA, Controversias ilustres y otras de más frecuente uso, trad. de Fidel Rodríguez Alcalde, Valladolid, Talleres Tipográficos Cuesta, 1931.

65 Juan de MARIANA, La dignidad Real y la Educación del Rey (De Rege et Regis Institutione), Introduccion y estudio preliminar de Luis Sánchez Agesta, Madrid, Centro de Estudios Constitucionales, 1981.

66 François Hotoman, La Gaule Francoise, Colónia, Par Hierome Bertulphe, 1574 (tradução em Francês).

67 De la puissance legitime du prince sur le peuple, et du peuple sur le prince. Traité tres-utile et digne de lecture en ce temps, escrit en latin par Estienne Junius Brutus ; et nouvellement traduit en François, 1581.

68 George Buchanan, De Jure Regni Apud Scotos, Edinburgh, 1579.

69 José Joaquim Gomes CANotilho e Vital MoreIRA, Constituição da República Portuguesa Anotada I, op. cit., p. 422.
} 
direito de resistência colectivo ("direito politico") contra formas de governo ou regimes carecidos de legitimidade" art. $21^{\circ}$ da $\mathrm{CRP}$, julgamos que está consagrado um direito individual de defesa, um direito de resistência passiva, e não um direito politico de resistência colectiva"1-. Por sua vez, considera-se que uma expressão do direito de resistência coletiva ou de insurreição dos povos contra "formas ditatoriais ou despóticas de governo ou ao domínio estrangeiro" se depara no artigo $7^{\circ}, \mathrm{n} .{ }^{\circ} 3$ da $\mathrm{CRP}^{72}$.

Não discordando totalmente desta interpretação, também não seria despropositado considerar-se que a primeira parte do artigo $21^{\circ}$ da CRP abrange tanto a resistência individual como a coletiva -tal como, comparativamente, tem sido feito para preceitos similares, v. g., da Constituição do Equador ${ }^{73}$, passando-se a encarar o n. ${ }^{\circ} 3$ do artigo $7^{\circ}$ da CRP como um complemento do artigo $21^{\circ}$ e expressão concreta desta última resistência política (embora numa intensidade superior). Seja como for, a verdade é que a CRP consagra de forma explícita ambas as resistências. Esta constatação é o primeiro argumento contra a tese da "metamorfose" do direito constitucional coletivo para um direito constitucional individual, defendida por Assunção Esteves.

Ao longo da sua dissertação de mestrado, a autora da escola de Lisboa, preconiza o ressurgimento da resistência popular da Idade Média (que tinha sido afastada pelo absolutismo iluminado), através de um processo de constitucionalização que o transformou em direito de resistência individual para defesa de direitos constitucionais. Atente-se, $v$. g., nas seguintes afirmações: "Debilitado durante a monarquia absoluta, o direito de resistência ressurge com o iluminismo, mas já com novas roupagens: é um direito individual-revolucionário, de tutela do individuo contra a opressão. Está, pois, já muito distante do "conservador" direito de resistência estamental. De direito moral-politico, o direito de resistência passa -se bem que com virtualidades, dadas as outras garantias dos direitos fundamentais-, com a sua positivação (constitucionalização), a consubstanciar uma tutela inorgânica e subsidiária dos direitos fundamentais; (...) $O$ direito de resistência não é considerado como a mesma ideia que vai sofrendo consagração

70 José Joaquim Gomes CANotilho, Direito Constitucional e Teoria da Constituição, op. cit., p. 521.

71 José Carlos Vieira de ANDRADE, Os Direitos Fundamentais na Constituição Portuguesa de 1976, op. cit., p. 340; cf. também, José de Melo ALEXANDRINO, Direitos Fundamentais - Introdução geral, op. cit., p. 110.

72 José Joaquim Gomes CANotilho e Vital MoReira, Constituição da República Portuguesa Anotada I, op. cit., p. 422.

73 "Los individuos y los colectivos podrán ejercer el derecho a la resistencia frente a acciones $u$ omisiones del poder público o de las personas naturales o juridicas no estatales que vulneren o puedan vulnerar sus derechos, y demandar el reconocimiento de nuevos derechos" (art. 98 ${ }^{\circ}$. $\mathrm{O}$ preceito constitucional equatoriano tem sido interpretado como direito de resistência do indivíduo e do povo. Sobre a constitucionalização do direito de resistência no Equador, $c f$. as recentes dissertações de David CoRDERo HEREDIA, El Derecho a la Resistencia y la Criminalización de la Defensa de los Derechos Humanos y la Naturaleza, Tesis de Maestria en Derecho, Mención en Derecho Constitucional, Universidad Andina Simón Bolívar, Ecuador, 2013 [Disponível em: http://hdl.handle.net/10644/3706 (consultado a 3 de Setembro de 2016)]; e Daniel Enrique SerRANo CAJAmARCA, La "Última Ratio" del Derecho Constitucional Ecuatoriano a la Resistencia, Tesis de Maestria en Derecho, Mención en Derecho Constitucional, Universidad Andina Simón Bolivar, Ecuador, 2015 [Disponível em: http://hdl.handle.net/10644/4391 (consultado a 3 de Setembro de 2016]. 
mais ou menos intensas, numa perspectiva linear, mas como algo que vê a sua função transmudada em cada um dos diversos periodos históricos, a saber: de garante da estabilidade dos poderes dos diversos corpos ou ordens, no Estado estamental, a tutela inorgânica e subsidiária de direitos fundamentais, no Estado constitucional" 74 .

É possível que a tese de Assunção Esteves seja tributária de uma censura à constitucionalização da resistência coletiva, que já vinha de trás, do pensamento doutrinário republicano, e se manteve durante o período do Estado Novo -aliás, ut supra, esta foi a doutrina mundial dominante até ao final da II Grande Guerra. Mas o facto de se recusar a resistência coletiva nos códigos constitucionais não justifica que se advogue uma "metamorfose" desta para um resistência individual. Mas a verdade é que, evangelizada a genealogia miscigenada do direito de resistência previsto pelo artigo $21^{\circ}$ da CRP, esta teoria passou a ser seguida e referenciada por investigadores nacionais ${ }^{75}$ e estrangeiros ${ }^{76}$.

No entanto, a tese de Assunção Esteves comete o pecado capital de não ter em conta a existência de uma resistência individual, em simultâneo com a resistência coletiva. Por outras palavras, na Idade Média também se acalentou e desenvolveu uma resistência do indivíduo contra eventuais abusos do poder público. Com certeza mais silenciosa, uma vez que lhe falta a literatura que eternizou a resistência politica do povo. Por isso, não faz sentido conjeturar gratuitamente uma transmutação da resistência coletiva para resistência individual, i. e., considerar que na Idade Média apenas existiu a resistência coletiva que, amordaçada pelo despotismo moderno, foi recuperada e metamorfoseada para resistência individual pelo constitucionalismo contemporâneo. Apesar de sedutor, o suceder cronológico não foi tão linear como se pretende fazer acreditar. Mas antes de demonstrar que ambas as resistências existem, a par e passo, há muitos séculos e se mantiveram no Estado constitucional até à hodiernidade, fica breve nota à positivação nos códigos constitucionais portugueses.

Portugal é um dos países pioneiros que constitucionalizou o direito de resistência ainda no século XIX, na Constituição Política da Monarquia Portuguesa de 1838: "É livre a todo o Cidadão resistir a qualquer ordem que manifestamente violar as garantias individuaes, se não estiverem legalmente suspensas” (art. 25\% ${ }^{77}$. Num projeto apresentado em 1837 às Cortes

74 Maria da Assunção Andrade Esteves, A Constitucionalização do Direito de Resistência, op. cit., p. 6 e p. 15.

75 Jorge Miranda e Rui Medeiros, Constituição Portuguesa Anotada I, op. cit., pp. 457-459; Jorge MiRAndA, Manual de Direito Constitucional IV - Direitos Fundamentais, op. cit., pp. 449-450; Catarina Santos Botelho, A tutela Directa dos Direitos Fundamentais: Avanços e recuos na dinâmica garantistica das justiças constitucional, administrativa e internacional, Coimbra, Almedina, 2010, p. 118.

76 V. g., Juan Ignacio UGARTEMEndíA ECEIZABARREnA, "El derecho de Resistencia y su 'Constitucionalización"', op. cit., p. 222; Mario TuRCHETTI, Tyrannie et Tyrannicide de l'Antiquité à nos Jours, op. cit., p. 959.

77 Ainda é manifesta a semelhança, salvo a parte final, com o preceituado na CRP de 1976. Curiosamente, vai ser a defesa da Constituição e da ordem constitucional (Constituição do Estado) que vai traduzir o direito de resistência nas constituições do século XX, v. g., na Constituição alemã -Marta SALAZAR SÁNCHEZ, "Pozitivización del Derecho de Resistencia en el Derecho Constitucional Alemán", in Revista Chilena de Derecho 20/2-3, 1993, pp. 323-332 [Disponivel em: 
Constituintes, pelo médico e deputado por Santarém, Manuel dos Santos Cruz (1792-1853), sugeria-se para o articulado da nova Constituição o seguinte: "em conspirando de facto contra a Constituição do Estado nenhuma Authoridade será obedecida; todo o individuo é competente para resistir-lhe, e toda a resistencia licita" (art. $14^{\circ}, 2 .^{a}$ parte) ${ }^{78}$. A norma do projeto inculca que, para além de uma resistência individual, o direito de resistência do povo à opressão também estava bem presente na teoria constitucional da época.

Apesar da vigência efémera da Constituição de 1838 (4 de Abril de 1838 a 10 de Fevereiro de 1842), ainda houve tempo para uma invocação do direito de resistência. No ano de 1840, a transferência de juízes feita por ordem de Costa Cabral fez com que alguns magistrados (ao que consta, seriam apenas dois) se insurgissem contra essa transferência invocando o direito de resistência, conforme revelam as palavras do senador V. Laborim, em ata de 28 de Outubro de 1840: "dos Juizes que o Governo transferiu, uns obedeceram e outros não, fiando-se no Artigo 25 da Constituição"79.

Trata-se de um exemplo concreto de resistência individual (exercido por mais do que uma pessoa) contra uma ordem do poder estadual considerada injusta. No entanto, a coetânea doutrina constitucional continuava vinculada ao direito de resistência popular contra os governos despóticos. V. g., Basílio Alberto de Sousa Pinto praticamente preenche o comentário ao artigo $25^{\circ}$ da Constituição de 1838 com o direito de resistência coletivo. Na Analyse da Constituição o autor chega à conclusão que existe uma diferença no exercício deste direito, conforme os governos sejam "livres" ou "despóticos": nos primeiros "é sempre empregado gradualmente, usando primeiro dos meios brandos; e só empregando os fortes, quando os brandos saem baldados: assim deve o Cidadão, primeiro, empregar o direito da petição; segundo, queixar-se por via da imprensa; terceiro, negar os subsidios ao Governo; quarto enfim resistir"; enquanto que nos segundos "estes como desconhecem e prosternam a opinião pública, esta não podendo manifestarse, quando aparece, é sempre armada da força, pois é aqui tudo"80. Conclusão que repete no Direito Público Constitucional, na forma seguinte: "O direito de resistência, como já dissemos, deriva do direito natural de defesa, e por isso se manifestará sempre sob toda e qualquer forma de Governo. Toda a diferença consiste em que debaixo de um Governo tirânico, em que os súbditos não podem fazer ouvir as suas queixas, quando os limites do sofrimento estão cheios, eles

http://dialnet.unirioja.es/servlet/ articulo?codigo=2649797 (consultado a 4 de Setembro de 2016]-.

78 Manuel dos Santos CRUZ, Projecto de Modificações à Constituição de 1822, Lisboa, Prensa Nacional, 1837, pp. 3-4 [Disponivel em: http://www.fd.unl.pt/Anexos/ Investigacao/1056.pdf (consultado a 4 de Setembro de 2016)].

79 Diário do Governo. Cortes. Câmara dos Senadores 68, p. 1443 [Disponível em: http://debates.parlamento.pt/ (consultado a 4 de Setembro de 2016)].

80 Basílio Alberto de Sousa PINTo, Analyse da Constituição Politica da Monarquia Portuguesa (manuscrito), 1838/39, comentário ao artigo $25^{\circ}$ da Constituição de 1838 [Disponível em: http://www.fd.unl.pt/Anexos/Investigacao/7367.pdf (consultado a 4 de Setembro de 2016)]. 
lançam mão dos últimos recursos. Enquanto nos Governos livres esta resistência é legal, e gradual's1.

$\mathrm{Na}$ vigência da Carta Constitucional (3. ${ }^{\circ}$ período: 1842-1910) Lopes Praça fala em resistência passiva e resistência violenta, admitindo "que um Principe, resolvido a conceder as garantias da liberdade a um povo immerso na ignorancia $e$ nas tradições do despotismo, não consignasse o direito de resistencia entre os direitos individuaes explica-se facilmente; mas que um povo habituado à liberdade não procure alcançar esta garantia seria inconcebivel”. Persevera, assim sendo, numa resistência popular em consonância com uma resistência que (à semelhança da Constituinte de 1838) deveria ser codificada entre os "direitos individuais"82.

A primeira Constituição republicana (1911) vai recuperar o preceituado pelo poder constituinte de 1838. O texto fundamental republicano, agora em artigo autónomo (art. $37^{\circ}$ ), prescreve que "é licito a todos os cidadãos resistir a qualquer ordem que infrinja as garantias individuaes, se não estiverem legalmente suspensas". Ao que tudo indica, "este número não se encontrava no projecto da Constituição - assevera Marnoco e Souza - foi ai introduzido em virtude de proposta do Sr. Dr. Barbosa de Guimarães"83. Como ficou dito, a letra deste preceito de 1911 vai ser alargada, passando a incluir a figura da legítima defesa, pela sucessiva Constituição de 1933 (art. 8º n. ${ }^{\circ} 19$ ), ficando definido que o cidadão português tem "o direito de resistir a quaisquer ordens que infrinjam as garantias individuais, se não estiverem legalmente suspensas, e de repelir pela força a agressão particular, quando não seja possivel recorrer à autoridade pública”.

O texto originário de 1976 vai trasladar a normativa de 1933 como parte integrante do art. $20^{\circ}$ (Defesa de direitos), atribuindo-lhe o número 2 e acentuando o seu carácter de mecanismo de defesa ou garantia. A primeira revisão ao texto constitucional originário, ocorrida no ano de 1982 através da Lei Constitucional n. ${ }^{\circ} 1 / 82$ de 30 de Setembro, desentranhou esse número 2 do art. $20^{\circ}$ para criar um novo artigo autónomo (art. $21^{\circ}$ ), sem qualquer alteração de conteúdo. A iniciativa da Lei Constitucional n. ${ }^{\circ} 1 / 82$, no que toca ao recémcriado art. $21^{\circ}$, cingiu-se ao patrocínio de uma nova epígrafe - "direito de resistência"-, o que ditou a alteração da anterior epígrafe "defesa de direitos" para "acesso ao direito e aos tribunais" (art. 20\%) ${ }^{84}$. Torna-se por demais evidente que a revisão de 1982, com a autonomização do direito de resistência em artigo apropriado, pretendeu demarcar estes mecanismos de autotutela (direito de resistência e legítima defesa) da heterotutela dos direitos constitucionais. Daí que, em sede de comissão eventual, se tenha entendido que o novo art. $21^{\circ}$ "não necessita de discussão uma vez que as alterações propostas são meramente de

81 Basílio Alberto de Sousa PINTo, Direito Público Constitucional (manuscrito), 1840, pp. 42-44 [Disponivel em: http://www.fd.unl.pt/Anexos/Investigacao/1503.pdf (consultado a 4 de Setembro de 2016].

82 José Joaquim Lopes PRAÇA, Direito Constitucional Portuguez I, op. cit., pp. 124-133 (132-133).

83 José Ferreira Marnoco e SouzA, Constituição Política da República Portuguesa, Comentário, op. cit., p. 157.

84 A epígrafe deste art. $20^{\circ}$ fixou-se, com a revisão de 1997, em "acesso ao direito e tutela jurisdicional efectiva". 
carácter sistemático e de modificação de uma epígrafe proposta pela FRS, com a qual a $A D$ concordou" "85.

Desde o primeiro momento que a doutrina do constitucionalismo republicano carrega consigo uma repulsa incipiente contra a resistência constitucional coletiva. Esta é associada à resistência agressiva ou "insurreição", que "tendente a forçar o governo a retirar as ordens injustas e ilegais" e que anuncia uma "inteira oposição entre Estado e sociedade", passivel de gerar uma revolução. Marnoco e Souza entende, por isso, que a Constituição republicana de 1911 se refere apenas à resistência passiva e defensiva e que a resistência agressiva, sob pena de conduzir à anarquia, não é nem pode ser prevista no texto escrito das constituições modernas ${ }^{86}$.

Marcello Caetano, nos anos cinquenta do século passado (a $1 .^{a}$ edição das Lições de Direito Constitucional e Ciência Política é de 1952), distingue a resistência individual da coletiva, tributando a primeira ao constitucionalismo português, desde a Constituição monárquica de 1838 -o que não é totalmente certo, como ficou supra demonstrado- e rejeitando a segunda, na esteira de Marnoco e Souza, por incitar à rebelião. Identifica como hipótese de resistência individual passiva a recusa de pagamento de impostos inconstitucionais (art. $8^{\circ}, \mathrm{n}^{\circ} 16$ da C.1933) e como hipótese de resistência individual ativa a resistência a uma atuação ilegal por parte de uma autoridade pública ${ }^{87}$.

Em suma, Portugal goza de uma recuada e quase impar tradição constitucional em relação ao direito constitucional de resistência: salvo os casos da Sicília (1812), do México (1814) e do Uruguai (1830), Portugal é dos primeiros Estados do mundo a positivar em texto constitucional o direito de resistência ${ }^{88}$. $\mathrm{O}$ que não quer dizer que tenha ficado imune à corrente segundo a qual o "muito do que em tirania é 'resistência' oprimida pelo Estado é na democracia de Estado de Direito oposição legal -parlamentar ou extraparlamentar- que faz parte do comportamento civico normal e se desenvolve em especial sob a protecção da liberdade de opinião e de reunião"89.

85 Diário da Assembleia da República, II - Série, 8 de Outubro de 1981 (Suplemento ao n. ${ }^{\circ}$ 108) p. 131 [Disponivel em http://debates.parlamento.pt/catalog.aspx?cid=r3. dar_s2rc (consultado a 4 de Setembro de 2016)].

86 José Ferreira Marnoco e SouzA, Constituição Politica da República Portuguesa, Comentário, op. cit., p. 157.

87 Marcello Caetano, Manual de Ciência Política e Direito Constitucional I, op. cit., p. 327.

88 Se levarmos em conta as Constituições históricas, a primordial positivação terá sido feita na Constituição Florentina de 1508 (cf. Patricio CARVAJAL, "Derecho de resistencia, derecho a la revolución, desobediencia civil. Una perspectiva histórica de interpretación. La formación del derecho público y la de la ciencia política en la temprana Edad Moderna", in Revista de Estudios Politicos 76, 1992, p. 77 [Disponivel em: http://www.cepc.gob.es/publicaciones/revistas/ revistaselectronicas?IDR=3\&IDN=233 (consultado a 13 de Janeiro de 2017)]; José Manuel NIETO SORIA, "La gestación bajomedieval del derecho de resistencia en Castilla: modelos interpretativos", in Cahiers d'Études Hispaniques Medievales 34, 2011, p. 15 [Disponível em: http://www.persee.fr/web/revues/home/prescript/article/cehm_17794684_2011_num_34_1_22 50 (consultado a 13 de Janeiro de 2017)].

89 Reinhold Zippelius, Teoria Geral do Estado, 3. ${ }^{a}$ edição, Tradução de Karin Praefke-Aires Coutinho, coordenação de J. J. Gomes Canotilho, Lisboa, Fundação Calouste Gulbenkian, 1997, p. 198. Juan Ignacio UGARTEMEndíA ECEIZABARRENA, "El derecho de Resistencia y su 'Constitucionalización”, op. cit., p. 244, assevera que "con el surgimiento de la Constitución 
Não deixa de ser verdade, que o direito de resistência politica coletiva, com o advento do constitucionalismo moderno e o pejar constante do Estado de Direito Democrático com múltiplos mecanismos de garantia $-v$. g., a separação de poderes, o recall, o direito à greve, o pluralismo partidário e o direito de oposição, os mecanismos de democracia participativa, o direito de petição, as liberdades de expressão, manifestação, associação e de imprensa, o poder de revisão constitucional, o mecanismos de fiscalização da constitucionalidade ${ }^{90}$ e a criação de tribunais constitucionais- viu o seu raio de ação assaz cerceado ${ }^{91}$.

Daí que seja compreensivel a hegemonia alcançada, na Época Contemporânea, pela resistência como defesa dos direitos fundamentais face às agressões perpetradas pelo poder estadual. $O$ que não impede, antes pelo contrário, que a resistência coletiva se mantenha latente e adormecida. De seguida, serão desfiados alguns subsídios esparsos, (V) para a genealogia préconstitucional do direito de resistência coletivo e, de seguida, (VI) para a genealogia pré-constitucional do direito de resistência individual.

democrática se consigue la juridificación democrática del histórico derecho de resistencia contra las injusticias del poder público ilegítimo en título o en ejercicio, la juridificación democrática de las formas de control del poder y garantía de los derechos y libertades”. Cf. também Ermanno ViTALE, Defenderse del Poder. Por una resistencia constitucional, op. cit., p. 11: "El derecho de resistencia en las "sociedades abiertas" parece ha passado a ser una antigualha, objeto de eruditos estúdios de historia del pensamiento politico, pero no un asunto de teoria política ni de debate público (...) Com la aparición y la consolidación progressiva del Estado democrático de derecho, dotado de múltiples mecanismos de garantia, todo indicaba que el viejo derecho de resistencia podia jubilarse tranquilamente sin que nadie lo lamentara".

90 O judicial review oriundo do constitucionalismo norte-americano (Marbury v. Madison, 1803), considerado um dos principais mecanismos de domesticação do direito de resistência [Edward L. Rubin, (2008): "Judicial Review and the Right to Resist", in Vanderbilt Public Law Research Paper n. ${ }^{\circ}$ 80-11, 2008, pp. 101-159 (129) [Disponivel em: http://papers.ssrn.com/sol3/papers.cfm? abstract_id=1139070 (consultado a 13 de Janeiro de 2017)]: "In short, judicial review domesticates the right of revolution"], foi introduzido na Europa através da Constituição republicana portuguesa de 1911 (art. $\left.6^{\circ}\right)$. Antes desta constitucionalização é conhecida a posição contrária do Supremo Tribunal de Justiça de 23 de Julho de 1907 - cf. António de ARAÚJO e Miguel Nogueira de BRITO, "Para a História da Fiscalização da Constitucionalidade em Portugal: Comentário ao acórdão de 23 de Julho de 1907 do Supremo Tribunal de Justiça", in Revista del Foro Constitucional Iberoamericano 5, 2004, pp. 107-115 [Disponivel em: https://e-archivo.uc3m.es/handle/ 10016/ 19054?locale-attribute=en (consultado a 13 de Janeiro de 2017)].

91 Juan Ignacio Ugartemendía EceizabarRena, "El derecho de Resistencia y su 'Constitucionalización”, op. cit., pp. 228-229; Roberto GARGARELlA, "La Última Carta. El derecho de resistencia en situaciones de alienación legal", in Seminario en Latinoamérica de Teoría Constitucional y Politica Papers (Paper 24), 2003 [Disponível em: http://digitalcommons.law.yale.edu/yls_sela/24 (consultado a 13 de Janeiro de 2017)]. Em suma, esta ideia vai de encontro à "resistência negativa do povo em parlamento" apregoada por Kant, que recusa qualquer resistência ativa por parte do povo - $c f$. Patricio LEPE CARRIÓN, "Widerstatd: El Valor de la Resistencia Politica en Immanuel Kant", in Nómadas. Revista Crítica de Ciencias Sociales y Juridicas 29, 2011 [Disponivel em: http://revistas.ucm.es/index.php/NOMA/article/view/NOMA1111140205A/25649 (consultado a 13 de Janeiro de 2017)]. 


\section{GENEALOGIA PRÉ-CONSTITUCIONAL DO DIREITO DE RESISTÊNCIA COLETIVO.}

Desde os tempos primordiais que, sob a monarquia portuguesa, lateja um "direito de resistência por sentença divina" (seguindo a catalogação sugerida por Nieto Soria), que se materializaria através de outra sentença outorgada pelo Papa $^{92}$. No início do século XIII, a bula de Honório III Quod solitae salutationis, de 22 de Dezembro de 1221, repreende D. Afonso II pelos excessos cometidos contra a Igreja e contra o arcebispo de Braga, ameaçando-o de absolver os seus vassalos do juramento de fidelidade e decretar o reino de Portugal como res nullius e passivel de ser concedido a outros o seu governo. Mas foi com o monarca seguinte que se consubstanciou o direito de resistência por sentença divina: D. Sancho II foi privado do exercício do poder político pela Bula de Inocêncio IV Grandi no immerito, de 24 de Julho de 1245. Os dois monarcas seguintes, D. Afonso III (1248-1279) e D. Dinis (1279-1325), ainda sentiram o peso das intimações pontificias, que ameaçaram levantar o juramento de fidelidade prestado pelos seus vassalos. A "resistência por sentença divina" é a tipologia apregoada e defendida por frei Álvaro Pais (c.1280-1352) no Speculum Regum (c. 1341) ${ }^{93}$. A propósito da morte do infante D. Pedro, em Alfarrobeira, um documento régio fala em "tempo da execução da duuinal(sic) justiça"94.

Para o âmbito de um "direito de resistência por incumprimento de pacto", o episódio ocorrido por volta do ano de 1355, durante a guerra civil que opôs el-rei D. Afonso IV e o infante sucessor D. Pedro I, foi o escolhido pelo franciscano catalão, Francesc Eiximenis, para ilustrar o típico direito de resistência ibérico na sua enciclopédia política Dotzè del Crestià (1387) ${ }^{95}$.

A resistência fiscal, enraizada na resistência medieval contra o pagamento de impostos que não tivessem sido aprovados em Cortes ${ }^{96}$, conta com copiosos e

92 José Manuel NiETO SORIA, "La gestación bajomedieval del derecho de resistencia en Castilla", op. cit., p. 16.

93 Álvaro PAIS, Speculum Regum / Espelho dos Reis, tradução de Miguel Pinto Meneses, Lisboa, 1955 , pp. 157 e ss. Esta tese viria a ser severamente contestada por Velasco Gouveia (15801659), na obra Justa Acclamação do Serenissimo Rey de Portugal Dom João IV (1644).

94 João José Alves Dias e Pedro Pinto (ed.), Cortes Portuguesas. Reinado de D. Afonso V: Cortes de 1439, Lisboa, Centro de Estudos Históricos, Universidade Nova de Lisboa, 2016, p. 35.

95 Xavier Renedo I PUIG, "Eiximenis, Alfonso IV, Pedro I de Portugal y sus vassalos", in Mirabilia: Revista Eletrônica de História Antiga e Medieval 15, 2012, pp. 288-317 [Disponível em: http://www.revistamirabilia.com/sites/default/files/pdfs/2012_02_13.pdf (consultado a 13 de Janeiro de 2017)].

96 Segundo o pensamento medievo os governantes não podiam "imponer ningún tributo; pues los impuestos son, según la concepción medieval, una confiscación del patrimonio. Por eso, el poder público sólo puede llevar a cabo esta injerencia en la propriedade privada com el acuerdo voluntario de todos los afectados (o, al menos, de sus representantes). Por tal razón, el impuesto medieval es, en realidade, una 'petición'”: Fritz KERN, Derecho y Constitución en la Edad Media, traducción, notas y estudio introductorio por Faustino Martínez Martínez, Valencia, Kyrios Gestión Cultural, 2013, p. 143. "Entre nós, o princípio de que o lançamento de impostos gerais só era legítimo quando obtivesse o acordo dos representantes da Nação [princípio da auto-tributação representativa ou da tributação consentida], ficou bem expresso a partir das Cortes de Coimbra de 1261": Raquel Sofia Quaresma Teixeira Campelo de SousA, As Garantias dos Contribuintes, Tese de Pós-Graduação em Direito Fiscal, Faculdade de Direito da Universidade do Porto, Centro de Investigação Jurídico Económica, 2005, p. 19 [Disponível em: http://www.cije.up.pt/publications/garantias-doscontribuintes (consultado a 13 de Janeiro de 2017)]. 
proeminentes exemplos coligidos por Margarida Mesquita no curso da História de Portugal, desde a problemática gerada, em meados do século XIII, pelo monetagium (que deu origem à célebre Lei de 126197) até à última prerrogativa exercida em reunião de Cortes de $1668^{98}$. A ligação direta desta resistência fiscal ao actual preceituado na CRP (art. $103^{\circ}$, n. $\left.^{\circ} 3^{\circ}\right)^{99}$ deve ser feita com algumas cautelas. É preciso ter em conta que, em tempos medievais, a resistência contra os impostos foi exercida pelo povo (através dos seus representantes) em parlamento e não de forma individual e subjetiva, como se prevê na Constituição actual. Pelo que, no mínimo, será muito questionável o pretenso vínculo e continuidade linear entre o atual preceito constitucional e a tradição histórica portuguesa de resistir a impostos aprovados fora do parlamento.

Após a batalha de Alfarrobeira (1449), o direito de resistência é invocado por ambas as partes em litígio: o defensor do infante D. Pedro, por um lado, e el-rei D. Afonos V, por outro. O Deão de Vergy, Jean Jouffroy, em defesa do finado regente invoca um direito de resistência apoiado em caudalosos fundamentos desarraigados a partir do Ius commune medievo ${ }^{100}$. Em oposição, a crença enviada por D. Afonso V, a el-rei de Castela, D. João II, está impregnada de um discurso de resistência contra a tirania. Toda a conduta do infante regente,D. Pedro, é descrita como própria de um tirano opressor, afirmando categoricamente que, $v$. g., o infante D. Pedro tinha sido eleito regente do reino "por tiranja mais que por Iustiça", que "o tyrano naturalmente auorresse os uirtuosos e com major Rezam aquelles que sub speçie de justiça com falças mostranças de fengida Religião prometendo liberdade tjrâniza os sobjeitos"101.

No ocaso da Idade Média, na De Republica Gubernanda per Regem (1496), do punho de Diogo Lopes Rebelo, ainda se levanta a questão do tiranicídio - "se o rei fosse tirano (o que Deus não consinta!), porventura poderia ser morto pelos súbditos?"- a que o autor responde negativamente; e só, em última instância, admite uma deposição pelo papa ou por um concílio geral ${ }^{102}$. A defesa do tiranícidio vai ser recuperada pelos autores da Escola de Salamanca, v. g.,

97 Este diploma faz parte da primeira Constituição Fiscal Portuguesa, segundo António de Castro Henriques, “A Primeira Constituição Fiscal Portuguesa (1250-1370)", in Ensaios na Tradição de Jorge Borges de Macedo, Lisboa, 2009, pp. 210-213. 93.

98 Maria Margarida Cordeiro MesquiTA, Direito de Resistência e Ordem Fiscal, op. cit., pp. 72-

99 "Ninguém pode ser obrigado a pagar impostos que não hajam sido criados nos termos da Constituição, que tenham natureza retroactiva ou cuja liquidação e cobrança se não façam nos termos da lei".

100 Manuel Francisco Ramos, Orationes de Jean Jouffroy em Favor do Infante D. Pedro (14491450) - Retórica e Humanismo Cívico, Dissertação de Doutoramento em Literatura, Porto, Faculdade de Letras da Universidade do Porto, 2006, pp. 180-232. Curiosa esta metáfora: “as abelhas produtoras de mel, se forem provocadas, não é verdade que ferem com os seus ferrões?” (p. 187).

101 João José Alves Dias e Pedro Pinto (ed.), Cortes Portuguesas. Reinado de D. Afonso V: Cortes de 1439, op. cit., pp. 31-38.

102 Diogo Lopes ReBelo, Do Governo da República pelo Rei: De Republica Gubernanda per Regem / Tratado das Produções das Pessoas [Divinas]: Tractatus de Productionibus Personarum [In Divinis], fac-simile das edições de Paris de fins do séc. XV, Versão em português de Miguel Pinto de Meneses, com um estudo de Manuel Cadafaz de Matos, Lisboa, Edições Távola Redonda, 2000, pp. 167-173. 
Fernando Vásquez de Menchaca ${ }^{103}$ e Juan de Mariana ${ }^{104}$, com repercussão por toda a Europa.

Compreensivelmente, as fontes legislativas medievais, bem ao invés da literatura política coeva, tendem a esquivar-se a um tratamento explícito do direito de resistência ativa do povo contra o poder tirânico do monarca ${ }^{105}$. As Partidas de Afonso X, aplicadas como fonte de Direito nos primeiros séculos da existência de Portugal, apesar de na Segunda Partida condenarem "todo ejercicio autoritario del poder, mediante la Ley VIII del Titulo I", não preveem um autêntico direito de resistência ${ }^{106}$. Da legislação lusa também destila um robusto compromisso do poder monárquico com o bem comum e a Justiça, mas sem qualquer alusão categórica à resistência do povo. Uma lei de D. Fernando (13671383), chamando à colação Aristóteles e os Doutores da Igreja, expressa abertamente a obrigação de o monarca fazer Justiça e prestar contas perante Deus (e não perante os homens), que, para tal, o nomeou seu vigário na terra ${ }^{107}$.

Mais sintomático é todo o incipit ao primeiro título do livro V das Ordenações Afonsinas, com passagens que fazem lembrar o brocardo de Santo Agostinho ("Rex eris si recte facias, si non facias non eris") e invocação de passagens das Sagradas Escrituras. Sem acolher expressamente o direito de resistência augura um estado real de muito curta duração para aquele que não cumpre com os ditames de Justiça ${ }^{108}$.

103 Fernando VÁzQuez DE MEnChaCA, Controversias ilustres y otras de más frecuente uso, trad. de Fidel Rodríguez Alcalde, Valladolid, Talleres Tipográficos Cuesta, 1931.

104 Juan de MARIANA, La dignidad Real y la Educación del Rey (De Rege et Regis Institutione), Introduccion y estudio preliminar de Luis Sánchez Agesta, Madrid, Centro de Estudios Constitucionales, 1981. Cf. Herald E. BRAUn, Juan de Mariana and Early Modern Spanish Political Thought, Ashgate, 2007, p. 6: "he seemed to combine a doctrine of popular sovereignty with a defence of the right of the private individual to kill not only the usurper of the throne but also the tyrannus ex parte exercitii (a legitimate ruler whose exercise of power marked her or him out as a tyrant)".

$105 \mathrm{O}$ direito de resistência do povo contra a opressão surge positivado, pela primeira vez em Portugal, no assento das Cortes de 5 de Março de 1641, Cf. Assento feito em cortes pelos tres estados dos Reynos de Portugal da acclamação, restituição \& juramento dos mesmos Reynos ao... Rey Dom Joaõ o Quarto deste nome, Lisboa, Paulo Craesbeeck, 1641, pp. 11-11v [Disponivel em: http:/ / purl.pt/12093 (consultado a 13 de Janeiro de 2017)].

106 Irina NANu, La Segunda Partida de Alfonso X el Sabio y la Tradición de los Specula Principum, Tesis Doctoral, València, 2013, pp. 268-273 [Disponivel em: http://roderic.uv.es/handle/10550/ 29240 (consultado a 13 de Janeiro de 2017)].

107 "nom querendo usar de justiça de que usar deve pera louvar os boons e justos e penar malfeitores mereceria de perder o nome e estado de Rey: e segundo outro sy o dito de Aristoteles, serião menos prezados dos homeens, e condapnados na Ley de Deos: e ainda, segundo disserom os Santos Doutores da nossa Sancta Fe Catolica, assy como antre os homeens Deos fez mais alto o Rey, $e$ lhe deu maior Estado, assy ante Deos nas penas do outro mundo, se justiça nom fizer, ou se leixar de a fazer, elle teraa o principal logo" (OA 2.60.1).

108 " $E$ pois que todo Rey, e Princepy antre todallas outras cousas deve principalmente amar, $e$ guardar justiça, deve-a guardar, e manteer em especial acerca dos peccados, e maldades tangentes ao Senhor Deos, de cuja maão tem o regimento, e seu Estado Real, como dito he; e aquelle, que o assy nom fezesse, deveria seer reputado por indigno, e desmerecedor da mercee, e beneficio, que delle recebeo; e assy como aquelle que ouvesse encorrido em peccado de ingratidooem, devia pouco durar seu Estado e senhorio" (OA 5.1.1) 
Um momento marcante da resistência contra um rei tirano foi protagonizado pelos revolucionários de 1640, para se libertar do jugo da dinastia de Castela. Elrei D. Filipe IV é considerando um rei tirano e "Por quanto, conforme as regras de direito natural, e humano, ainda que os Reynos transferissem nos Reys todo o seu poder, e Imperio, para os governarem, foy debaixo de huma tacita condição, de os regerem, e mandarem com justiça sem tyrania. E tanto que no modo de gouernar vzarem della, pòdem os Pouos priualos dos Reynos, em sua legitima, e natural defensão, e nunca nestes casos forão vistos obrigarse, nem o vinculo do juramento estenderse a elles"109.

Saltando para o século do constitucionalismo escrito ou codificado, o direito de o povo se poder autodeterminar e resistir contra governos opressivos vai ter manifesto acolhimento no seio das duas capitais revoluções do constitucionalismo moderno -a Revolução Americana (1776) ${ }^{110}$ e a Revolução Francesa (1789)111 e destila de incipientes documentos da Revolução Liberal portuguesa como, v. g., o Manifesto aos Portugueses da Junta Provisional do Governo Supremo do Reino, de 24 de Agosto de $1820^{112}$. Não surpreende, por isso, que a Constituinte de 1838 lhe tenha reservado um espaço no interior do seu articulado.

\section{GENEALOGIA PRÉ-CONSTITUCIONAL DO DIREITO DE RESISTÊNCIA INDIVIDUAL.}

O direito de resistência do indivíduo não goza da copiosa literatura jurídicopolítica do direito de resistência do povo. O primeiro tratado jurídico sobre esta

109 Assento feito em cortes pelos tres estados dos Reynos de Portugal da acclamação, restituição \& juramento dos mesmos Reynos ao... Rey Dom Joã̃ o Quarto deste nome, Lisboa, Paulo Craesbeeck, 1641, p. 11-11v [Disponivel em: http://purl.pt/12093 (consultado a 13 de Janeiro de 2017)].

110 Declaração dos Direitos do bom povo da Virginia, 12 de Junho de 1776; Declaração de Independência dos Estados Unidos da América, 4 de Julho de 1776; Constituição da Pensilvânia 1776 (art. VI); Constituição de Vermont 1777 (art. VI e art. VII); Constituição de Massachusetts 1780 (art. VII e art. VIII); Constituição de Maryland 1776 (art. IV); Constituição de New Hamshire de 1784 (art. X). Cf. Tom Ginsburg, Daniel LAnsberg-Rodriguez e Mila Versteeg, "When to Overthrow your Government: The Right to Resist in the World's Constitutions", op. cit., pp. 12031206.

111 Declaração dos Direitos do Homem e do Cidadão, 26 de Agosto de 1789 (art. 2\%); Constituição Francesa 1793 (art. 35\%). O projeto constitucional de 1946, que foi declinado por referendo, repetia este último preceito de 1793. Mesmo assim, o direito de resistência foi incorporado ex vi do preâmbulo da Constituição, que integra a Declaração de 1789 ("Le peuple français proclame solennellement son attachement aux Droits de l'Homme et aux principes de la souveraineté nationale tels qu'ils ont été définis par la Déclaration de 1789"), e faz parte do bloco de constitucionalidade. $C f$. Tom Ginsburg, Daniel Lansberg-Rodriguez e Mila Versteeg, "When to Overthrow your Government: The Right to Resist in the World's Constitutions", op. cit., pp. 12061207.

112 Documentos para a Historia das Cortes Geraes da Nação Portugueza (1883), Lisboa, Imprensa Nacional, 1883, Tomo I, pp. 9-10 [Disponivel em http://purl.pt/12101 (consultado a 13 de Janeiro de 2017)]. É curiosa a analogia com o momento fundacional, no campo de Ourique, em pleno século XII: "Nos gloriosos campos de Ourique o exercito levanta a voz, e apparece a monarchia; hoje, no berço de Portugal, o exercito levanta a voz, e salva da destruição e da ruina este precioso deposito, confiado à sua guarda, e sustentado pelo valor de um braço invencivel, depois de muitos seculos de existencia”. 
temática -que terá estado na origem do instituto italiano da defensa- é a Summa Trium Librorum de Rolando de Luca. Foi escrita por Rolando, um juíz e notário da cidade italiana de Luca, no final do século XII (1195-1197), com base em fragmentos do novo Direito justinianeu ${ }^{113}$.

Em Portugal, só a título meramente incidental se pode encontrar referência esporádica em diploma legal avulso ou em caso concreto minimamente documentado, que tenha sobrevivido à rasoira do tempo. Uma menção legislativa escrita que me foi possivel compilar consta nos foros extensos ou "foral velho" da vila de Aveiro, cinzelado e promanado por ordem do coevo corregedor no meirinhado da Beira, Afonso Eanes, em assembleia concelhia de 21 de Março de 1342. Pela sua singularidade e supina utilidade para a causa fica aqui, para análise futura, uma transcrição na íntegra dessa passagem:

\begin{abstract}
"Jtem Dizem que esta de custume que o que asy aqui for Vizinho non leuar pão nem Binho do selleiro senon Jouuer em Renda ao Mordomo que o Mordomo achacara e chamara muitas Vezes a Juizo e estremadamente tres quartas feiras de quaresma que Va correr os lobos hu chamão a fonte do Morgado e se the o chamado frontar com tres mialhas non the cayra na coima e se destas cousas nenhuma non fes pagara sesenta soldos de coima ao Mordomo e se afrontar na caza e esto tem o Comçelho por estranho.

Jtem este custume Dis ô corregedor que he mao em serem os homens achaquados a muitas Vezes e que sobre esto manda, e defende ao Mordomo que nom achaque nenhum nem o Chame maliçiozamente pello espeitar sem dereito e se Algum chamar duas Vezes e fora sobre duas uezes que a tresseira non the responda e defenda the que dy adiante non possa mais chamar sobre aquillo de que Ja foi Absolto e quanto he o dos Lobos correr e da pea delles aguardesse o custume antigo aatá ha que lhe el Rey tolha e a el o queira fazer saber a el Rey"114
\end{abstract}

Tentando glosar o português arcaico: os vizinhos da vila de Aveiro queixamse de serem coagidos a pagar certas "luvas" (pão e vinho do seleiro) ao oficial de el-rei (mordomo), caso contrário, eram oprimidos por este para comparecerem constantemente a juízo e irem correr os lobos na Quaresma, sob pena de uma coima no valor de sessenta soldos por cada vez que faltassem. O corregedor classifica este costume de mau (injusto) e manda e defende ao mordomo que não chame ninguém maliciosamente ou sem razões de Direito para responder perante a Justiça. No caso de alguém já ter sido chamado duas vezes, o corregedor reconhece-lhe um legitimo direito de resistência, escusando-se terminantemente a comparecer e defendendo-se contra a ordem ilegal do mordomo, alegando que este os não podia chamar à Justiça sobre causa julgada de que estavam absolvidos.

Por outras palavras, este vetusto preceito consuetudinário, da primeira metade do século XIV, determina de forma expressa um direito de resistência do indivíduo à violação do seu direito constitucional segundo o qual "ninguém pode

113 Emanuele CONTE, "Defensa: Resistance against unjust power in the Medieval Learned Law (12 ${ }^{\text {th }}-13^{\text {th }}$ Centuries)", in Revolten und politische Verbrechen zwischen dem 12. und 19. Jahrhundert Rechtliche Reaktionen und juristisch-politische Diskurse / Revolts and Political Crime from the 12th to the 19th Century. Legal Responses and Juridical-Political Discourses, Frankfurt am Main, 2013, pp. 121-133

114 José Domingues e Pedro Pinto, “O Foral Velho da Vila de Aveiro de 1342", in e-SLegal History Review 21, 2015, pp. 14-15 [Disponivel em: http://www.iustel.com/v2/revistas /detalle_revista.asp?id=15\&numero=21 (consultado a 13 de Janeiro de 2017)]. 
ser julgado mais do que uma vez pela prática do mesmo crime” (art. $29^{\circ}$, n. ${ }^{\circ} 5$ CRP). Trata-se do principio "ne bis in idem" (C 9.2.9.pr.) ${ }^{115}$, oriundo da jusromanística, que impede que alguém seja submetido a processo duas vezes pelo mesmo facto, e consta enunciado em lei de D. Dinis, de 21 de Fevereiro de 1304, compilada e comentada nas Ordenações de D. Afonso V (OA 5.101).

Não surpreende que a legislação monárquica medieva, à semelhança do direito de resistência do povo, opte por omitir qualquer direito de resistência do indivíduo. A sua constante e suma preocupação é, sem sombra de dúvida, a de evitar e punir severamente a resistência ilegitima e injustificada ao poder, sobretudo, ao poder judicial. Até porque os representantes do monarca gozam de uma certa sacralidade: uma vez que o rei é considerado o vigário de Deus, será lícito que os seus representantes também sejam considerados pessoas sagradas a quem, por isso, se deve plena obediência ${ }^{116}$. Esta fórmula consta de forma lapidar no incipit de uma lei de D. Afonso V:

\begin{abstract}
"Todo aquel que for degradado per ElRey ou per alguum seu official que pera ello tenha seu poder deve trabalhar como a todo seu conprido leal e verdadeiro poder sigua $e$ mantenha conpridamente o degredo que lhe for posto, sem alguuma arte e maao engano ca em outra guisa será pugnido gravemente segundo adiante será declarado; ca escripto he na Ley de Deos que aquelle que nom obedece a seu Rey ou Principe e trespassa seu mandado peca mortalmente porque resistindo a seu mandado resiste ao mandado de Deos pois de sua Maão recebeo seu Alto e Real Estado e todo o poderio que tem por que rege e governa o Regno em Justiça. E disserom os Theollegos que ainda que o condapnado por ElRey a morte possa fogir e escapar a ella, nom o deve fazer e fogindo peca gravemente polla razaom suso dita. E em outra parte se lee na Santa Escriptura que toda creatura humana deve seer muito obediente a seu Rey ou Principe como cosa animada por Deos enviada a este mundo pera em seu Nome reger e governar o Regno ou Enperio que the he encomendado a louvor dos boons e castigo dos dos maaos. E por esto se póde bem dizer que todo aquelle que sem necessidade ou pressa muito evidente trespassa mandamento de seu Rey e Senhor deve asparamente seer escarmentado por tal que a pena a el dada seja aos outros exemplo pera no cairem em similhante caso. E aquel Rey que leixa trespassar seus mandados sem pena razoada nom deve seer theudo por justo porque nom seendo seus mandamentos geeralmente conpridos nunca poderia seer muito temudo de seu povoo e por conseguinte converia-lhe per razom necessaria perder o nome de justo pois sua Justiça nom traz a fim de boa e real eixecuçom" (OA 5.67.pr.)
\end{abstract}

Esta passagem estirada desvenda todo o principio de obediência medieval ao poder público. Saliente-se, no entanto, que apesar de "o dever de obediência ser justamente considerado como um dos elementos fundantes e estruturantes de toda a sociedade medieval"117, não pode passar em branco a ressalva de desobediência consignada em casos de "necessidade ou pressa [prema (opressão)?] muito

115 "Qui de crimine publico in accusationem deductus est, ab alio super eodem crimine deferri non potest” (O que por um crime público foi objeto de uma acusação, não pode ser acusado do mesmo crime por outro).

116 Miguel PINO ABAD, "El Delito de Resistencia a la Justicia en Castilla (Siglos XIII-XVIII)", in eSLegal History Review 19, 2015, pp. 1-32 [Disponivel em: http://www.iustel.com/v2/revistas/detalle_revista.asp?id=15\&numero=19 (consultado a 14 de Janeiro de 2017)].

117 Nuno BRANDÃo, "Desobediência e Resistência a Ordens de Autoridade no Período das Ordenações", in Direito Penal. Fundamentos Dogmáticos e Político-Criminais. Homenagem ao Prof. Peter Hünerfeld, Coimbra, Coimbra Editora, 2013, p. 1184. Cf. outras passagens das Ordenações -v. g., OA 5.91.pr.- que testemunham esta realidade. 
evidente". Ou seja, embora todo o incipit doutrinário esteja vocacionado para o princípio da obediência ao poder público, não deixou de acautelar plausível ressalva em casos de necessidade extrema ou opressão muito evidente.

Fica apenas este singelo indício, que permite concluir que a resistência medieval também pode consubstanciar uma vertente individual, em que todo e cada um dos membros da comunidade política está obrigado a defender o Direito (e não apenas o seu direito subjetivo), mesmo frente ao poder público. O facto de a resistência do indivíduo ter sido expurgado dos textos legislativos e da doutrina juspolitica, em nada obsta ao seu reconhecimento e a uma tenacidade bem acesa na consciência jurídica social. Ao contrário da contemporaneidade legalista e codificadora, nesses tempos o conceito de Direito não se esgota em textos escritos. A Idade Média não conhece uma ordem escrita que pretenda abraçar toda a realidade jurídica, mas apenas uma ordem jurídica parcialmente documentada ou registada, o "registro siempre permanece como una pequeña pieza de aquella totalidade, el Derecho, la cual única e exclusivamente vive en el corazón de la comunidade juridica"118.

\section{CONCLUSÃO.}

A relação entre governantes e governados é um terreno demasiado lamacento e escorregadio que coloca sérios desafios à Teoria Constitucional e à Ciência Politica, tal como este do direito de resistência. A primeira questão que se coloca a este tema de todos os tempos é a de saber se o direito de resistência deve ou não ser positivado no texto jusfundamental de cada Estado. A tendência para a sua não positivação, que vinha associada ao constitucionalismo dos séculos XVIII e XIX, acabou por se inverter, sobretudo, a partir da segunda metade do século $\mathrm{XX}$. Não admira, por isso, que este tema ganhe novos foros de interesse para a ciência do Direito Constitucional.

A abordagem historicista ao direito de resistência poderá constituir um primordial amparo para uma delimitação conceptual. Antes de mais, nada obsta a que o direito de resistência seja tratado em simultâneo com a legítima defesa, tal como o faz o atual art. $21^{\circ}$ da Constituição portuguesa, mas sem que isso dispense uma "separação das águas". Fica aqui a sugestão de, na esteira da Constituinte de Timor Leste, aproveitar uma próxima revisão constitucional para se proceder a uma delimitação formal entre estas duas formas de resistência constitucional. Acima de tudo, as duas tipologias de resistência devem ser diferenciadas nos seus contornos materiais de aplicação prática.

O polimorfismo do direito de resistência não se fica pelas eventuais analogias ou afinidades com a legitima defesa. Existem múltiplas e diversas formas de resistência, exercidas com um grau de intensidade muito variável. Desde logo, o direito político de resistência popular e o direito de resistência individual. $O$ constitucionalismo moderno português tendeu para uma sobrevalorização deste último, relegando o famigerado direito de resistência político para o (praticamente olvidado) n. ${ }^{\circ} 3$ do artigo $7^{\circ}$ da CRP. Mas esta hegemonia não pode ser interpretada como uma recuperação do direito de resistência coletivo, oriundo da Idade Média, e a sua transmutação em direito de resistência individual.

118 Fritz KERN, Derecho y Constitución en la Edad Media, op. cit., p. 101. 
Para este trabalho coligiram-se muito breves referências esparsas ao longo de séculos para as três formas de resistência constitucional -legítima defesa, direito de resistência coletivo e direito de resistência individual- no intuito de contribuir para aclarar o escurso histórico de cada uma delas em Portugal e, concomitantemente, desfazer o equívoco de uma eventual metamorfose do direito de resistência coletivo para direito de resistência individual.

Enviado el (Submission Date): 17/01/2017

Aceptado el (Acceptance Date): 20/02/2017 